\title{
DO INFORMATION AND COMMUNICATION TECHNOLOGIES EMPOWER FEMALE WORKERS? FIRM-LEVEL EVIDENCE FROM VIET NAM
}

\section{Natalie Chun and Heiwai Tang}

NO. 545

May 2018
ADB ECONOMICS WORKING PAPER SERIES 


\section{Do Information and Communication Technologies Empower Female Workers? Firm-Level Evidence from Viet Nam}

Natalie Chun and Heiwai Tang

No. 545 | May 2018
Natalie Chun (nchun@adb.org) is an Economist at the Asian Development Bank. Heiwai Tang (hwtang@jhu.edu) is an Assistant Professor at Johns Hopkins School of Advanced International Studies and a Research Fellow at the Center of Economic Studies and Ifo Institute.

We thank Elisabetta Gentile for detailed comments. 
(C) 2018 Asian Development Bank

6 ADB Avenue, Mandaluyong City, 1550 Metro Manila, Philippines

Tel +632632 4444; Fax +6326362444

www.adb.org

Some rights reserved. Published in 2018.

ISSN 2313-6537 (print), 2313-6545 (electronic)

Publication Stock No. WPS189352-2

DOI: http://dx.doi.org/10.22617/WPS189352-2

The views expressed in this publication are those of the authors and do not necessarily reflect the views and policies of the Asian Development Bank (ADB) or its Board of Governors or the governments they represent.

ADB does not guarantee the accuracy of the data included in this publication and accepts no responsibility for any consequence of their use. The mention of specific companies or products of manufacturers does not imply that they are endorsed or recommended by ADB in preference to others of a similar nature that are not mentioned.

By making any designation of or reference to a particular territory or geographic area, or by using the term "country" in this document, $A D B$ does not intend to make any judgments as to the legal or other status of any territory or area.

This work is available under the Creative Commons Attribution 3.0 IGO license (CC BY 3.0 IGO)

https://creativecommons.org/licenses/by/3.0/igo/. By using the content of this publication, you agree to be bound by the terms of this license. For attribution, translations, adaptations, and permissions, please read the provisions and terms of use at https://www.adb.org/terms-use\#openaccess.

This CC license does not apply to non-ADB copyright materials in this publication. If the material is attributed to another source, please contact the copyright owner or publisher of that source for permission to reproduce it. $\mathrm{ADB}$ cannot be held liable for any claims that arise as a result of your use of the material.

Please contact pubsmarketing@adb.org if you have questions or comments with respect to content, or if you wish to obtain copyright permission for your intended use that does not fall within these terms, or for permission to use the ADB logo.

Notes:

In this publication, "\$” refers to United States dollars.

ADB recognizes "China" as the People's Republic of China and "Vietnam" as Viet Nam.

Corrigenda to ADB publications may be found at http://www.adb.org/publications/corrigenda. 


\section{CONTENTS}

TABLES AND FIGURES

ABSTRACT

$\begin{array}{ll}\text { I. INTRODUCTION } & 1\end{array}$

II. LITERATURE REVIEW 4

III. CHANGING INFORMATION AND COMMUNICATION TECHNOLOGY 5 POLICIES, TECHNOLOGICAL ADOPTION, AND GENDER DIFFERENCES IN THE LABOR MARKET

$\begin{array}{lll}\text { IV. } & \text { DATA }\end{array}$

A. Firm-Level Data $\quad 7$

B. Provincial Measures of Information and Communication Technology Quality 7

C. Sector Measures 9

V. CONCEPTUALFRAMEWORK

VI. REGRESSION SPECIFICATIONS AND IDENTIFICATION STRATEGY 12

VII. EMPIRICAL RESULTS

A. The Effects of Information and Communication Technology on 13

Female Employment

B. The Effects of Information and Communication Technology on 16

Skilled Employment

C. Differential Effects across Industries 19

VIII. CONCLUDING REMARKS

$\begin{array}{ll}\text { APPENDIX } & 23\end{array}$

$\begin{array}{ll}\text { REFERENCES } & 40\end{array}$ 


\section{TABLES AND FIGURES}

\section{TABLES}

$1 \quad$ Quality of Broadband Internet across Select Countries 1

2 Summary Statistics of the Information and Communication Technology Variables 8

3 Firms' Female Labor Shares and Adoption of Information and Communication 14 Technology (Ordinary Least Squares)

$4 \quad$ Firms' Female Labor Shares and Adoption of Information and Communication 15 Technology (Two-Stage Least Squares)

$5 \quad$ Firms' Colleged-Educated Labor Shares and Information and Communication 17 Technology Adoption (Two-Stage Least Squares)

6 Firms' Female Labor Shares among Colleged-Educated Workers and Information 18 and Communication Technology Adoption (Two-Stage Least Squares)

$7 \quad$ The Differential Effects of Information and Communication Technology on Firms' $\quad 20$ Female Labor Shares across Industries (Task Complexity)

8 The Differential Effects of Information and Communication Technology on Firms' 21 Intensity of Nonroutine, Manual and Physical Tasks

A.1 Major Policies that Improve Information and Communication Technology Capability 23

A.2 Viet Nam Labor Force Statistics by Gender 23

A.3 Viet Nam Monthly Wages for Wage Workers by Gender and Education 24

A.4 Number of Enterprises 24

A.5 Summary Statistics of Viet Nam's Manufacturing Enterprise Surveys 25

A.6 Five Different Aspects of Information and Communication Technology Quality 27

A.7 Female Comparative Advantage and Task Complexity by Industry 34

\section{FIGURES}

$1 \quad$ Internet and Broadband Penetration 3

2 Information and Communication Technology Index by Province 9 


\begin{abstract}
This paper studies the effects of firms' investments in information and communication technologies (ICT) on their demand for female and skilled workers. Using the gradual liberalization of the broadband Internet sector across provinces from 2006 to 2009 as a source of exogenous variation to identify the causal impacts of ICT, we find evidence from the country's comprehensive enterprise survey data that firms' adoption of broadband Internet and other related ICT increased their relative demand for female and college-educated workers. The effect of ICT on firms' female employment is particularly strong among the college-educated workers, and is stronger in industries that are more dependent on highly manual and physical tasks. These results suggest that ICT can lower gender inequality in the labor market by shifting the labor demand from highly manual, routine tasks in which men have a comparative advantage toward more nonroutine, interactive tasks in which women hold a comparative advantage. However, the effect of ICT is weaker in industries relying more on complex and interactive tasks, suggesting that gender differences in education may have limited female labor supply for the most innovative industries that require highly technical skills to complement ICT.
\end{abstract}

Keywords: gender inequality, ICT, information technology, infrastructure, wage inequality

JEL codes: I24, J16, J21, J22 


\section{INTRODUCTION}

Since the 1990s, advances in information and communication technologies (ICT) across the world have substantially changed the way people live, work, and interact. The ICT revolution has reduced the distance between individuals, lowering the costs of information acquisition and coordination of activities within and between firms. Accompanying these changes has been the rapid rise in income inequality within countries, which has caught significant attention from both policy makers and academics.' Developed countries facing strong pressure from globalization and import competition, particularly from the People's Republic of China, have experienced rising labor market polarization and wage inequality. ${ }^{2}$ However, research on the interplay between ICT and labor market inequality has been relatively sparse for developing countries, despite the increasing importance of ICT in creating opportunities for employment and economic growth in these countries.

There are numerous reasons why the labor market effects of ICT and globalization could deviate from those of developed markets, such as high informality of labor markets, limited capacity to provide complementary skills, and depressed wages. Our paper contributes to the literature on income inequality by studying how ICT affects female and skilled employment within firms. In contrast to the research that focuses on developed countries, we explore the research question using firm-level data from Viet Nam, a large developing country. In particular, we study how firms' ICT adoption, triggered by Viet Nam's central government policy to develop broadband Internet infrastructure, changes firms' employment by gender and skill groups.

Table 1: Quality of Broadband Internet across Select Countries

\begin{tabular}{lcc}
\hline & $\begin{array}{c}\text { Speed } \\
\text { (bits per second } \\
\text { per Internet user) }\end{array}$ & $\begin{array}{c}\text { Affordability } \\
\text { (\$ per month) }\end{array}$ \\
\hline PRC & 6,530 & 19 \\
Indonesia & 6,584 & 29 \\
Cambodia & 17,792 & 12 \\
Viet Nam & 24,374 & 3 \\
Malaysia & 34,119 & 10 \\
Philippines & 37,409 & 22 \\
Thailand & 64,907 & 19 \\
United States & 99,147 & 16 \\
\hline
\end{tabular}

PRC = People's Republic of China.

Source: World Bank. World Development Indicators. http://databank.worldbank.org/ data/reports.aspx?source=world-development-indicators (accessed 10 October 2017).

\footnotetext{
For example, Piketty's 700-page "Capital in the Twenty First Century" (2014) has drawn global attention.

2 See Autor, Dorn, and Hanson (2016) for a comprehensive review on the effects of the so-called "China shock" on developed economies.
} 
Studying the employment effects of ICT in Viet Nam comes with several additional strengths. The country's enterprise survey data contain unique and detailed information about various types of ICT in which a firm invested over several years. In addition, the central government of Viet Nam implemented policies to liberalize the broadband Internet sector between 2006-2008, which we exploit in constructing the instruments for firms' adoption of ICT. In particular, the policies aimed to provide coverage in the most impoverished provinces since 2007. The reform encouraged private firms to enter the Internet sector, driving up market competition and thereby lowering prices while enhancing the quality of Internet services. ${ }^{3}$ The monopoly power of state-owned enterprises in the broadband Internet sector was substantially reduced. As a result of several years of bold ICT reforms, Viet Nam has become the country with the highest penetration rates of ICT among developing countries, offering greater opportunities for firms to use digital technology to acquire information for both production and sales. According to World Bank's World Development Indicators for 2015, Viet Nam's broadband Internet was one of the most affordable in the world and its average Internet speed was faster than both the People's Republic of China and Indonesia (see Table 1).

An important contribution of the paper is the construction of several indexes capturing the quality and accessibility of broadband Internet in Viet Nam, which we use as instruments for firms' adoption of ICT. These instruments vary across provinces and time from 2005 to 2009 , due to the Government of Viet Nam's sequential implementation of reforms to improve the broadband Internet infrastructure. Using these province-specific time-varying instruments, we establish the causal effect of firms' ICT on their demand for skilled and female workers, respectively. Due to the reforms, the number of firms adopting various ICT increased significantly. In particular, between 2007 and 2008, the fraction of firms using broadband Internet increased by $20 \%$. Figure 1 shows significant upward trends of the (log) number of workers with computers connected to the Internet, workers with computers connected to local area network (LAN), the fractions of firms having Internet access, LAN, and websites, respectively since 2005.

Using the firm panel data set over the 2005-2009 period, we find that within the same industry and region, firms that adopted broadband Internet and other related ICT raised their relative demand for female and college-educated workers, respectively. Specifically, we find that a $10 \%$ increase in a firm's number of computers connected to broadband Internet induces the firm to increase the share of female workers by about 3.5 percentage points. This amounts to roughly a $10 \%$ increase over the $32 \%$ baseline share of females employed by Vietnamese firms in our sample. Firms that have access to broadband Internet, compared to those that did not, have a female labor share that is on average 14 percentage points higher. The effect of ICT on firms' female employment is even stronger among college-educated employees-the female labor share in the college-educated workforce of firms that adopted broadband Internet is on average $46 \%$ higher than those that did not.

The effect of ICT on firms' female employment is particularly strong among college-educated workers, and is stronger in industries that depend more on highly manual and physical tasks, according to the United States (US) Department of Labor's Occupational Information Network (O*Net) task database for occupations in the US. These results suggest that ICT may have shifted the relative demand for different tasks, in which male and female workers have different comparative advantages. They are consistent with the findings by Pitt, Rosenzweig, and Hassan (2012) that males have a comparative advantage in brawn while females have a comparative advantage in skills, contributing to

3 Key regulatory changes are listed in Appendix Table A.1. Increased competition has also coincided with Viet Nam's accession to the World Trade Organization which significantly reduced tariffs on imports of information and communication technology (ICT) products from 2007 to 2010. 
a relatively larger return to investments in schooling for females. In our study, the rise of ICT raises the marginal product of nonroutine, interactive tasks, shifting the demand for tasks that favor females. ${ }^{4}$ However, the effect is weaker in industries that rely more on complex and interactive tasks. These findings suggest that gender differences in education, specifically in technical training, may have limited the supply of female labor in more complex sectors due to fewer females having the critical technical skills required for undertaking the more complex technical tasks.

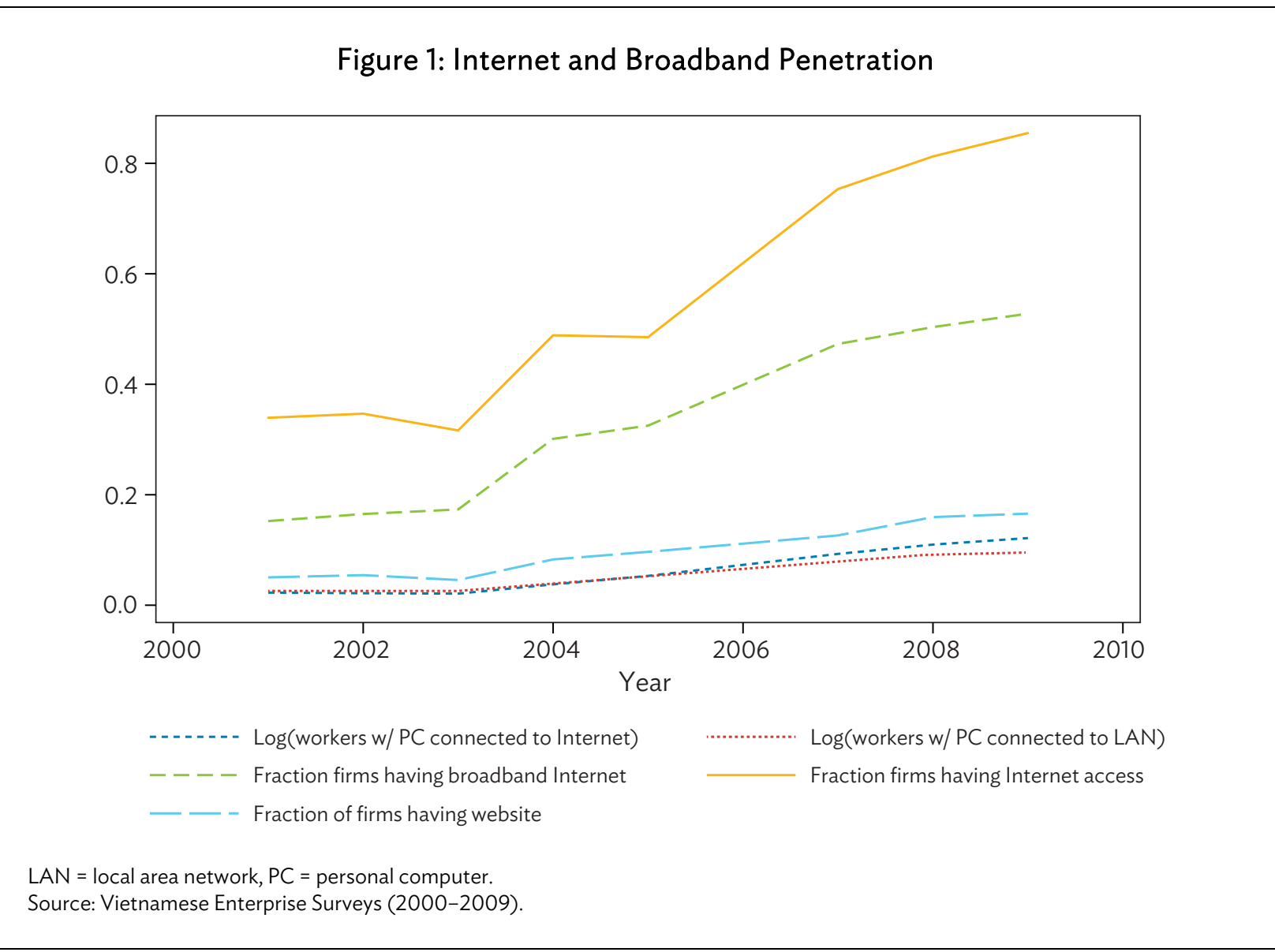

Research findings of this paper will offer important development policy implications for Viet Nam and developing countries in general. Low wages and barriers to education in developing countries imply that there may be vastly different effects of ICT adoption on labor market outcomes, compared to developed countries. Larger information asymmetry and market frictions in developing countries imply more significant economic gains from ICT investments. In developing countries, females often face greater disadvantages of accessing formal employment opportunities leaving them more vulnerable to poverty. These disadvantages arise from perceived gender roles that limit job access, differences in levels and types of education and training, and a higher degree of labor-intensive firms employing highly manual and physical processes.

4 Consistent with this conjecture, Black and Spitz-Oener (2010) find that in Germany, partly driven by computerization, women have experienced a relative increase in their supply of nonroutine analytic and interactive tasks, while there is no such change in the task supplied by men. See the literature review for a more detailed discussion. 
The paper proceeds as follows. Section II provides a literature review. Section III discusses the policy changes that happened during the sample period, which offer an instrument for the regression analysis. Section IV discusses the data source and the construction of the key variables. Section $V$ discusses the conceptual framework and outlines two testable hypotheses. Section VI presents our empirical specifications, followed by section VII that presents the empirical results. The final section concludes.

\section{LITERATURE REVIEW}

This paper has wide ranging implications and contributes to four broad strands of literature. First, it relates to the research on the effects of ICT on firm performance. Black and Lynch (2001) find that increased use of computers by nonmanagerial employees raise firms' productivity. Brynjolfsson and Hitt (2003) use a sample of US firms to show that firms' computerization is associated with faster productivity and output growth, especially in the long run. ${ }^{5}$ Bartel, Ichniowski, and Shaw (2007) find that after adopting new IT-enhanced equipment, plants produce more customized products, experience efficiency growth, and raise the demand for skilled machine operators. Using data for thousands of firms in Brazil and India, Commander, Harrison, and Menezes-Filho (2011) find positive effects of and significantly larger returns to ICT investment than those documented for developed countries. ${ }^{6}$ A subset of this literature focuses on the impact of ICT on firms' organizational changes (e.g., Bresnahan, Brynjolfsson, and Hitt 2002; Bloom et al. 2014). For instance, Tambe, Hitt, and Brynjolfsson (2012) show that in the US the extent of firms' external focus is correlated with both their information technology investment and organizational decentralization.

Second, our paper contributes to the literature on the relationship between ICT and labor market outcomes. Autor, Katz, and Krueger (1998) show that computerization of production raises the relative demand for college-educated workers in US industries. Crandall, Lehr, and Litan (2007) find that a 1 percentage point increase in ICT penetration in a US state is associated with 0.2-0.3 percentage point higher employment. Forman, Goldfarb, and Greenstein (2012), however, find a quantitatively small effect of ICT adoption on employment and wage growth across US counties. Using industry-level panel data for 11 advanced economies, Michaels, Natraj, and Van Reenen (2014) find that industries with faster ICT growth are associated with a larger demand for highly educated workers. Using Norwegian firm-level data, Akerman, Gaarder, and Mogstad (2015) show that broadband Internet improves the labor market outcomes and productivity of skilled workers.

Third, our work contributes to the literature on gender inequality in the labor market. ${ }^{7}$ The seminal paper by Autor, Levy, and Murnane (2003) shows that ICT is more substitutable for routine tasks, which require relatively little interaction and communication between people, while complementing nonroutine tasks. Black and Spitz-Oener (2010) find that in Germany, women have experienced a relative increase in their supply of nonroutine analytic and interactive tasks. The relative decline in females' supply of routine tasks, partly driven by technological changes, contributed to a substantial closing of the gender wage gap. Ngai and Petrongolo (2017) develop a formal model to show how the rise of the service economy driven by technological changes benefits women who have a

5 The authors emphasize the importance of complementary investments that amplify the productivity effect of ICT, such as organization capital, that take time to be implemented.

6 Other studies include Grimes, Ren, and Stevens (2012), who use both propensity score matching and instrumental variable approaches to show that in New Zealand broadband adoption raises firm productivity by $7 \%$ to $10 \%$. Ogutu, Okello, and Otieno (2014) find that farms in Kenya that adopt ICT are more productive, partly because of information about input uses.

7 See Goldin's (2006) Ely Lecture at the American Economic Association Meeting for a discussion about the economic, sociological, and political factors behind the trends of female labor market performances in the US in the 20th century. 
comparative advantage in supplying services. Based on micro data from multiple countries, Olivetti and Petrongolo (2016) find that cross-country variation in industrial structure explains the bulk of the differences in labor demand between the US and other countries, and about one-third of the overall cross-country differences in wage and hour gaps. Our work is closely related to Juhn, Ujhelyi, and Villegas-Sanchez (2014), who link ICT to changes in gender inequality in a developing country. They find rising females' relative wage and employment in Mexico in blue collar jobs, due to trade-induced computerization that lowered firms' demand for physically demanding tasks.

While digital technologies have brought many changes to job compositions, closing the gender employment gap, it could be driving gender inequalities in the most innovative and highly skilled sectors. For instance, Lindley (2012) finds that while the overall gender gaps have closed in the United Kingdom, females have lost ground in certain sectors, such as finance and machine manufacturing, which have experienced the fastest changes related to computerization. A hypothesis is that the underlying social prejudice against female students acquiring technical skills and knowledge may have limited the female labor supply response to an increased demand for highly technical tasks.

Fourth, this paper is broadly related to the impact of ICT on poverty and inequality in developing countries. Existing studies reveal that new technologies and infrastructure investments will not always benefit people equally and can sometimes have adverse consequences (e.g., Duflo and Pande 2007). In South Africa, electrification was found to significantly raise female employment, but led to increasing wage inequality between males and females (Dinkelman 2011). One of the more notable positive findings has been the study by Jensen (2007), who shows that mobile service provision helped reduce information asymmetry, reducing price volatility and thus excess supply by fisherman in India. In Africa, the Internet was found to have significantly contributed to improved employment prospects and declines in job inequality between less educated and more educated workers in 13 of the 14 countries examined (Hjort and Poulsen 2017).

In Viet Nam, the interplay between ICT, task complexity, and female labor market outcomes might be very different because wages in high-skilled sectors are still relatively low, resulting in different implications on the gender wage gap compared to developed countries. Furthermore, constraints on the availability of highly skilled labor might make it more difficult to complement complex technological processes leading to relatively less skilled sectors experiencing faster ICT adoption and contributing more to economywide growth and the closing of the gender gap in the short run.

Our paper contributes to these strands of research by providing firm-level evidence of the effects of ICT on firms' employment and organizational structure, focusing on firms' relative demand for female workers. We also examine how the employment of ICT varies across industries based on their task complexity.

\section{CHANGING INFORMATION AND COMMUNICATION TECHNOLOGY POLICIES, TECHNOLOGICAL ADOPTION, AND GENDER DIFFERENCES IN THE LABOR MARKET}

The liberalization of the telecommunications sector has created vast improvements in access to ICT in Viet Nam. In a little over a decade, Viet Nam's strategic investments have transformed it from a Southeast Asian laggard to a leader in technological competitiveness. In 2005, access to the Internet in Viet Nam was poor with available bandwidth of 44 bits per second per person. However, according to the World Bank's World Development Indicators, by 2015 its bandwidth had risen to more than 24,000 bits per second per person with entry level plans available for only $\$ 3$ per month providing an extremely low threshold for firm's and individuals to access the Internet (see Table 1 for details). 
Efforts to liberalize the telecommunications sector started in 2002, with the Ministry of Post and Telecommunications passing legal regulations to foster competition in the sector that had been previously monopolized by state-owned enterprises. A series of policies that provided for joint ventures opened the path to competitiveness bringing ICT investments and protocols that were in line with global standards, increasing speed, expanding access, and driving down prices. The government envisioning ICT as a driver of social change also invested heavily in conducting monitoring and evaluation to understand the dynamic effects of ICT investments across the provinces. By 2011, ICT provision was competitive with 90 different Internet providers and five companies providing cellular data (Tuan 2011).

Viet Nam's accession to the World Trade Organization complemented improvements in ICT infrastructure by substantially reducing the costs of importing various equipment including computers and machines and introducing greater competition into the ICT sector by paving the way for foreign direct investment. The removal of tariffs between 2007-2009 caused average tariffs on ICT equipment to sink to $9.2 \%$ in 2010 compared to $14.5 \%$ in 2005 (WTO 2017). The combination of improved Internet speed and affordability accompanied by price reductions in technological equipment were primary drivers of the rapid expansion in the number of households and firms using the Internet since 2005. By 2015, the Internet penetration rate was above 50\% of the population providing significant incentives for firms concentrated on the domestic market to leverage Internet technologies to grow their business (World Bank 2017). Appendix Table A.1 lists the major policy changes that affect the quality and cost of ICT in the country.

Against the backdrop of changing ICT is a labor market with relatively minimal differences in labor market participation. According to Viet Nam's Labor Force Surveys, in 2013, 85\% of males and 77\% of females ages 15-64 were participating in the labor force (see Appendix Table A.2). Still, gender differences continue to operate through employment and wage outcomes. Like many developing countries, the informal sector characterizes a large proportion of the population and female workers are less likely to participate in formal wage work at $30 \%$ compared to $40 \%$ of males. While gender wage gaps have declined between 2007 and 2013, particularly among workers with a lower level of education, men still made about 15\%-30\% higher wages that could be driven by different occupations, tasks, and skills (see Appendix Table A.3). These patterns suggest that ICT could play an important role in closing gender gaps in employment outcomes if ICT adoption improves the relative returns to the comparative advantage that females have in tasks, inducing firms to offer higher wages and more stable employment.

Despite progress in ICT, the availability of higher order skills could be a major constraint to Viet Nam's ambitions to become a premier ICT country. Within the country, only a small percentage of the population has the necessary ICT skills to complement more complex computerized and digital tasks. Males continue to dominate the science, technical, engineering, and mathematics (STEM) degrees driven in part by biases within the country that view males as more capable in performing technical jobs. ${ }^{8}$ This has potentially led to significant gender gaps in the proportion of females trained in STEM degrees in Viet Nam even while there is near parity in matriculation to higher education (Nguyen 2013). Education and skills ultimately could play a large role in the incentives of firms to adopt ICT and their demand for female labor across industries. ${ }^{9}$

8 While there has been a rapid increase in the the share of youth going onto tertiary education, the share remains small in the overall labor force at $<10 \%$.

9 Newman and Tarp (2014) suggest that most technological adoption has been low-tech and concentrated on adoption of machines to complement human labor and using computer for basic processes rather than implementing aggressive strategies on the Internet for market expansion. 


\section{DATA}

\section{A. Firm-Level Data}

The main data source of this paper is the Annual Enterprise Census of Viet Nam, over the period of 2005-2009, conducted by the General Statistics Office (GSO) of Viet Nam. The GSO conducts the annual census of all enterprises, across both manufacturing and nonmanufacturing sectors, operating in the country. The censuses cover state-owned, collectively owned, private, and foreign enterprises. The enterprise censuses contain detailed balance sheet information of each firm. For example, each firm's total employment, employment by skill and gender, capital, revenue, expenses, profits, liabilities, and most importantly, investments in various ICT are reported.

A unique aspect of the Vietnamese enterprise censuses is its comprehensive and detailed information on firms' use of ICT. Specifically, the censuses contains indicators of a firm's usage of personal computers, access to Internet, usage of LAN, emails, websites, and usage of digital methods for purchase and sales transactions. Each firm has a unique firm identifier, that can be used to construct a firm panel data set. Thus, an analysis on firms' productivity growth and changing employment structure can also be conducted. Table 2 provides summary statistics of firms' key ICT variables and other characteristics that are used in the regression analysis. Appendix Table A.5 summarizes these key firm variables and also their female labor shares used in the regression sample. It shows that by 2009 , Internet penetration reached nearly $86 \%$ of all firms in the sample, but that more modern e-commerce activities were far smaller with only $17 \%$ of all firms having a website. Female employment in formal firms is unequal at 33\%. For 2006, the GSO of Viet Nam did not report information on firms' ICT in their surveys, implying that we have to exclude 2006 from the main regression sample. Appendix Table A.4 reports the number of firm observations included in the regression sample by broad sector and year.

Partly due to the reforms described in section III above, firms across Viet Nam have been significantly increasing their usage of ICT over time. Figure 1 shows the averages of firms' measures of adoption of ICT-log number of workers with computers connected to the Internet, log number of workers with computers connected to LAN, the fractions of firms having Internet access, LAN, and websites, respectively. These five firms' ICT measures, which were all increasing over the sample period on average, will be the main regressors of interest in the regression analysis below.

\section{B. Provincial Measures of Information and Communication Technology Quality}

To construct the instrument for firms' adoption of ICT, we use a second data source that provides province-level panel data on ICT quality, compiled and made publicly available by Viet Nam's Ministry of Science and Technology. The index captures a province's readiness for ICT and has been available since 2005. It was designed to be a policy tool for local governments to identify their jurisdictions' ICT efficiency and reduce income inequality in the region by enhancing households' and firms' technological access. There are five indexes that aim to capture the different aspects of ICT development, namely technical infrastructure, human infrastructure, applications, manufacturing and businesses, and organization and policy environments. Our analysis focuses on the ICT's technical infrastructure, which is based on actual adoption of and investments in various types of ICT technologies, ranging from fixed telephone lines, Internet accounts, broadband and mobile phone subscribers per household, the number of broadband companies providing services in the region, among others. 
Table 2: Summary Statistics of the Information and Communication Technology Variables

\begin{tabular}{|c|c|c|c|c|c|c|c|c|c|c|c|c|}
\hline & Short Name & 2001 & 2002 & 2003 & 2004 & 2005 & 2006 & 2007 & 2008 & 2009 & 2010 & 2011 \\
\hline $\begin{array}{l}\text { Number of Obs } \\
(w / \text { info on ICT) }\end{array}$ & & 18,691 & 22,588 & 25,132 & 33,240 & 42,708 & & 46,101 & 48,470 & 52,733 & 51,696 & 80,253 \\
\hline \multicolumn{13}{|l|}{ Continuous variables } \\
\hline Number of PCs & so_pc & $\begin{array}{r}6.83 \\
(18.31)\end{array}$ & $\begin{array}{r}7.58 \\
(25.88)\end{array}$ & $\begin{array}{r}6.46 \\
(27.07)\end{array}$ & $\begin{array}{r}8.47 \\
(33.77)\end{array}$ & $\begin{array}{c}8.43 \\
(38.00)\end{array}$ & - & $\begin{array}{c}11.1 \\
(42.11)\end{array}$ & $\begin{array}{r}12.03 \\
(41.89)\end{array}$ & $\begin{array}{c}13.27 \\
(74.35)\end{array}$ & $\begin{array}{r}14.62 \\
(130.13)\end{array}$ & $\begin{array}{r}12.73 \\
(51.93)\end{array}$ \\
\hline $\begin{array}{l}\text { Number of PCs } \\
\text { connected to Internet }\end{array}$ & pc_int & $\begin{array}{c}1.14 \\
(7.45)\end{array}$ & $\begin{array}{r}1.45 \\
(13.99)\end{array}$ & $\begin{array}{r}1.47 \\
(12.72)\end{array}$ & $\begin{array}{r}2.78 \\
(21.85)\end{array}$ & $\begin{array}{c}3.7 \\
(26.19)\end{array}$ & $\begin{array}{l}- \\
-\end{array}$ & $\begin{array}{r}6.73 \\
(23.79)\end{array}$ & $\begin{array}{r}8.79 \\
(31.57)\end{array}$ & $\begin{array}{r}10.36 \\
(38.79)\end{array}$ & - & - \\
\hline $\begin{array}{l}\text { Number of PCs } \\
\text { connected to LAN }\end{array}$ & pc_lan & $\begin{array}{r}2.39 \\
(13.67)\end{array}$ & $\begin{array}{c}2.87 \\
(20.03)\end{array}$ & $\begin{array}{c}2.71 \\
(19.93)\end{array}$ & $\begin{array}{r}4.36 \\
(29.64)\end{array}$ & $\begin{array}{r}5.05 \\
(31.89)\end{array}$ & $\begin{array}{l}- \\
-\end{array}$ & $\begin{array}{r}7.32 \\
(38.06)\end{array}$ & $\begin{array}{c}9.67 \\
(38.50)\end{array}$ & $\begin{array}{c}10.57 \\
(43.47)\end{array}$ & - & $\begin{array}{l}- \\
-\end{array}$ \\
\hline $\begin{array}{l}\text { Fraction of PC } \\
\text { Connected to Internet }\end{array}$ & & 0.17 & 0.19 & 0.23 & 0.33 & 0.44 & - & 0.61 & 0.73 & 0.78 & - & - \\
\hline \multicolumn{13}{|l|}{ Dummies } \\
\hline Have PC? & $\mathrm{dpc}$ & 0.9 & 0.88 & 0.84 & 0.94 & 0.87 & - & 0.99 & 0.99 & 0.98 & 0.99 & 0.98 \\
\hline Access to Internet? & dint & 0.35 & 0.35 & 0.32 & 0.5 & 0.49 & - & 0.76 & 0.82 & 0.86 & - & - \\
\hline Have LAN? & dlan & 0.16 & 0.17 & 0.18 & 0.31 & 0.33 & - & 0.48 & 0.51 & 0.53 & - & - \\
\hline $\begin{array}{l}\text { Have electronic } \\
\text { transactions? }\end{array}$ & demail & 0.08 & 0.07 & 0.07 & 0.04 & 0.04 & - & 0.02 & 0.03 & 0.02 & - & - \\
\hline Have website? & dweb & 0.05 & 0.06 & 0.05 & 0.08 & 0.1 & - & 0.13 & 0.16 & 0.17 & - & 0.24 \\
\hline
\end{tabular}

ICT = information and communication technology, LAN = local area network, $\mathrm{PC}=$ personal computer.

Note: Firms with over 20 employees or above are surveyed. Observations with missing values on revenue, material, or total expenses are dropped. Sample means of each variable are reported, with standard errors reported in parentheses.

Source: Annual Enterprise Census by the General Statistics Office of Viet Nam. 
The human infrastructure index is comprised of integration of computerization classes in education and governmental staff using computers in their work. The ICT applications index captures governmental agencies openness to ICT through provision of websites and digitalization of operations. The ICT manufacturing or business index focuses on business measures production of ICT. Finally, the ICT policy environment index aims to capture openness by the local government to drive ICT growth and adoption. See Appendix Table A.6 for the constituents of the index by year.

To check the robustness of our main results, we use an overall index that is a weighted average of the five indexes. Both the overall and technical infrastructure ICT indexes vary substantially across provinces and time, allowing us to use them as instruments to predict a regions' ICT efficiency and thus firms' cost and adoption of various ICT technologies in the first stage. Figure 2 shows the time trend of the ICT technical infrastructure index for each of the eight regions in Viet Nam. Across the regions, there is a general upward trend in the ICT infrastructure index. Some regions, such as the Red River Delta and Mekong Delta regions, started with a higher level of ICT. These regional differences will be accounted for by region fixed effects in the regressions.

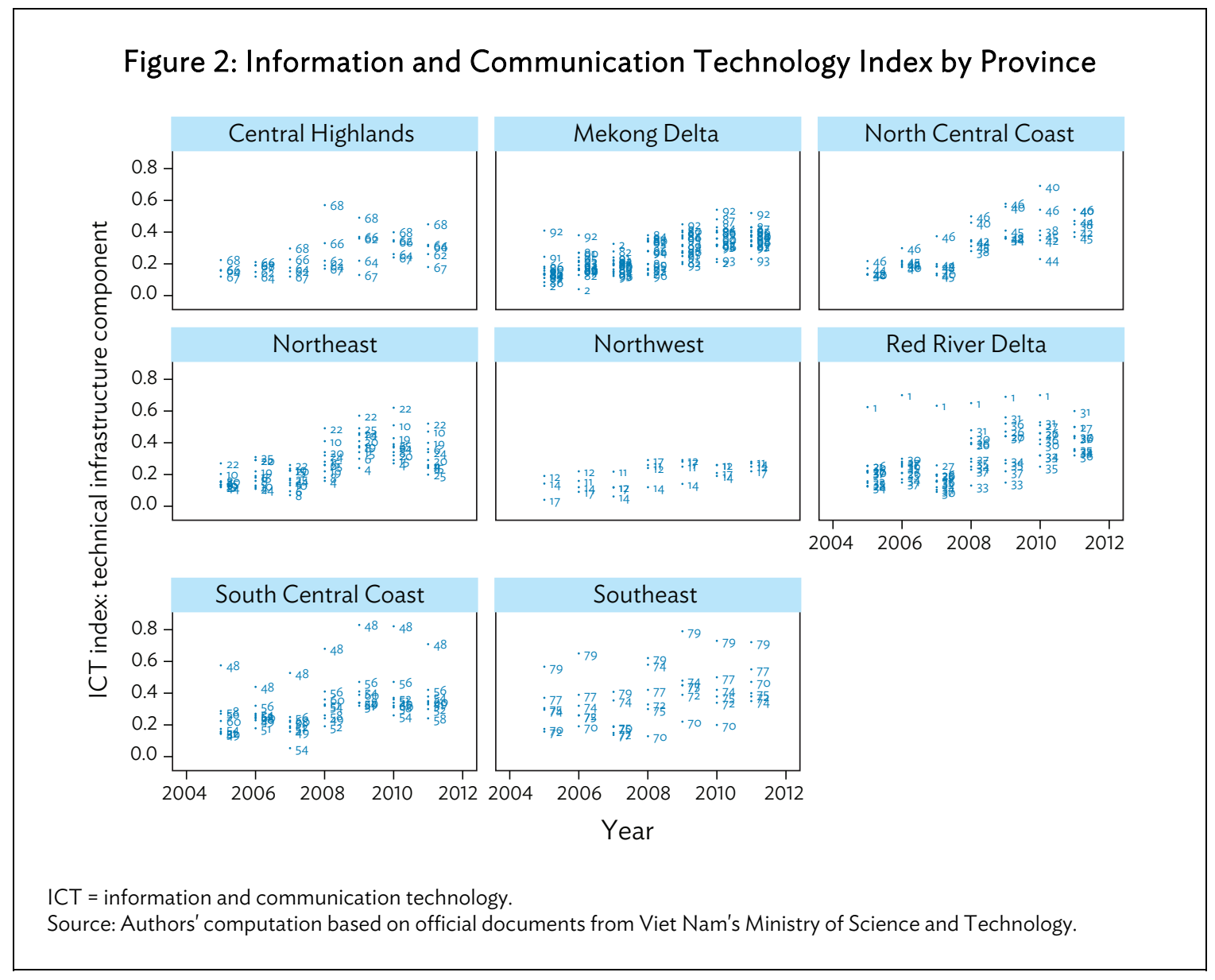

\section{Sector Measures}

In the last section of the paper, we examine whether the effects of ICT on firms' employment patterns vary across industries. In particular, we relate the effects to the complexity of the tasks involved in the production processes and the extent of female comparative advantage of the industry. We measure an 
industry's task complexity using measures from Keller and Yeaple (2008). The foundation of their measures is at the occupation level. The authors construct an index on an occupation's complexity, which is a measure of the degree to which complex problem solving skills are needed to evaluate options and implement solutions in a given occupation according to O*NET, as the basis of an industry's task complexity. More complex sectors are those sectors which rely heavily on highly technical, engineering skills and are the most innovative sectors of an economy while less complex are industries providing basic services and products. A US North American Industry Classification System (NAICS) 6-digit industry's task complexity is the weighted average of the tasks, with weights equal to the fractions of occupations in the industry based on data from the US Current Population Surveys. The 6-digit NAICS is harmonized to the international standard classification of occupations 2008 (ISCO2008) at the 3-digit level.

We also draw on measures from Acemoglu and Autor (2011) capturing the degree to which tasks in an occupation are nonroutine, manual, and physical using occupation data from $\mathrm{O}^{*} \mathrm{NET}$ in 2007. These measures are constructed to have mean value of 0 and a standard deviation of 1 . They can potentially capture strong gender differences in occupations that relate to comparative advantages that different genders face in supplying labor for different types of tasks. This data is connected by occupation to data on total employment defined by the US Census's Current Population Survey, covering both manufacturing and nonmanufacturing sectors. ${ }^{10}$ This data is then collapsed to a distinct NAICS 3-digit code which is then mapped into the latest International Standard Industrial Classification codes revision 4.4 (ISIC rev 4.4), using a concordance file from the website of the United Nations Statistics Division. Food services, mining, and manufacturing are some of the industries requiring more manual and physical labor while industries that are far less physically intensive are in the ICT sector and marketing." See Appendix Table A.7 for details about these two sector measures at the 3-digit ISIC level.

\section{CONCEPTUAL FRAMEWORK}

In this section, we outline a conceptual framework that provides a guide for understanding the interplay between firms' demand for tasks, ICT adoption, and employment by skill and gender groups. To this end, we borrow the key features and assumptions of the task model of Autor, Levy, and Murnane (2003). Their model assumes that firm production requires tasks that can be described broadly along two dimensions: routine versus nonroutine and manual versus analytic or interactive. Thus, tasks can be grouped into four broad categories of routine interactive, routine manual, nonroutine interactive, and nonroutine manual. Autor, Levy, and Murnane (2003) provide some specific examples from the Dictionary of Occupational Titles for each of the four categories (see Table 1 in their paper). Routine interactive tasks include, for example, record-keeping, calculation, and repetitive customer service. Routine manual tasks include picking, sorting, and repetitive assembly. Nonroutine interactive tasks include forming and testing hypotheses, legal writing, marketing, and sales. The classic examples of nonroutine manual tasks include driving and janitorial services. It is also assumed that tasks differ along a dimension of complexity where more complex tasks require higher order thinking and problem solving skills that are critical to building innovative products. For example, software development and scientific research are occupations relying more heavily on complex tasks.

Intuitively, we can expect that computerization and ICT are more substitutable for routine tasks that are repetitive and codifiable. It is probably more difficult to completely substitute nonroutine

10 Industries are classified based on the US Census 2007 classification.

1 United Nations Statistics Division. https://unstats.un.org/unsd/cr/registry/regot.asp?Lg=1. 
tasks that often involve unexpected contingencies, such as driving on the road, with ICT. ${ }^{12}$ Based on these intuitions, Autor, Levy, and Murnane (2003) develop a model that features constant elasticity of substitution and production functions that use routine labor, nonroutine labor, and computer capital as inputs. Their model makes three assumptions, which we modify in the context of ICT as:

(i) ICT is more substitutable for human labor in carrying out routine tasks than nonroutine tasks.

(ii) Routine and nonroutine tasks are themselves imperfect substitutes.

(iii) Greater intensity of routine inputs increases the marginal productivity of nonroutine inputs.

Making the same set of assumptions, we can expect that an increase in ICT usage by firms will reduce their relative demand for routine tasks but raise their relative demand for nonroutine tasks. What is new in our framework is that we have workers differentiated by gender in terms of their comparative advantage in different tasks. Existing empirical research provides some evidence that females have a comparative advantage in nonroutine, interactive tasks, while men have a comparative advantage in the manual and physically intensive tasks. As a result of the rise in digital technologies, there has been a relative increase in the complementary value of interactive, service-oriented tasks compared to tasks that require little interaction (Mathiowetz et al. 1985, Guiso et al. 2008, and Black and Spitz-Oener 2010). This suggests that there is a higher complementary value between ICT and nonroutine, interactive tasks where females have a comparative advantage compared to ICT and tasks that are noninteractive and physical.

With the assumption of this mapping, we have the following testable hypothesis.

Hypothesis 1: All else equal, a firm's adoption of ICT has a positive effect on the share of female employment if ICT is more complementary to nonroutine interactive tasks for which females have a comparative advantage.

Nevertheless, task complexity may play a significant role in labor demand that cuts along gender dimensions due to differences in education and skills training. Males may have a stronger comparative advantage in more complex and highly technical tasks because there are far more males that have science, technical, engineering, and mathematics (STEM) training compared to females. This is consistent with the finding of Lindley (2012) and basic statistics from both developing and developed countries that show men train in (STEM) fields in far higher proportions compared to females (e.g., UNESCO and KWDI 2015).

Since we do not observe the task components of each worker in our data, it is hard to verify directly our assumption about males' comparative advantage in tasks that are more complementary to ICT, but are also highly complex requiring a specific set of technical skills. However, if our assumption is right, we should expect a weaker effect of ICT on female employment in sectors that are more dependent on technical and complex skills, due to a higher extent of training in STEM among males compared to females. In other words, in sectors that depend on more complex, interactive, and communication-intensive tasks, the effects of ICT proposed in Hypothesis 1 should be weaker. We summarize these predictions in the following hypothesis, which we will empirically examine in the last part of the analysis:

12 With the recent innovations in driverless cars, the claim that nonroutine tasks such as driving, which traditionally was not much affected by ICT and artificial intelligence more specifically, needs to be revisited. 
Hypothesis 2: The effects of ICT on firms' female labor shares are weaker in industries that depend more on complex tasks, for which ICT is complementary, due to a lower acquisition of STEM skills among women.

\section{REGRESSION SPECIFICATIONS AND IDENTIFICATION STRATEGY}

To examine the effects of ICT adoption on firms' share of female workers in total employment, we estimate the following specification:

$$
\frac{f_{i t}}{l_{i t}}=\alpha+\beta I C T_{i t}+X_{i t} \delta+\left[F E_{r}+F E_{j}+F E_{t}\right]+\omega_{i t}
$$

where $i, r, j, t$ stand for firm, province, industry, and year, respectively. The dependent variable $f_{i t} / l_{i t}$ stands for the share of female workers $\left(f_{i t}\right)$ in firm i's total employment $\left(l_{i t}\right)$ in year $t$.

On the right-hand side of (1), the main independent variable $I C T_{i t}$ is one of the following five firm measures of ICT:

(i) (log) Number of personal computers (PCs) per worker,

(ii) (log) Number of PCs connected to broadband local area networks (LAN) per worker,

(iii) have access to broadband Internet,

(iv) have access to Internet, and

(v) have a company website.

Notice that the first two measures are continuous variables, while the last three measures are dummy variables, which take the value of 1 if the firm has adopted the corresponding ICT, 0 otherwise. A positive and statistically significant estimate of $\beta$ will provide support to Hypothesis 1 .

The variable $X_{i t}$ is a vector of firm-level controls, including firm sales, employment, fixed asset, employment (all in logs), as well as age, foreign ownership dummy, state ownership dummy. The variable $F E$ stands for fixed effects, which include region $\left(F E_{r}\right)$ (8 of them), sector ( $F E_{j}$ ) (11 of them), and year $\left(F E_{t}\right)$ (4 of them) fixed effects, respectively, to capture any time-invariant unobserved factors that may affect a firm's decision to adopt ICT. ${ }^{13}$ For instance, the Red River Delta in northern Viet Nam, which contains the country's capital Ha Noi, started with a higher level of ICT infrastructure. As shown in Figure 2, the Red River Delta region appeared to have a higher ICT index compared to other regions in 2005. Sector fixed effects control for the varying importance of ICT across industries. For example, firms in the agriculture, forestry and fishing sector have a lower average ICT adoption rate than those in manufacturing. Year fixed effects control for the overall macro trends of ICT adoption, such as the positive correlation between income per capita and the use of technology.

13 See the list of sectors in Appendix Table A.4 and that for regions in Figure 2. 
As firm productivity and managerial capabilities are unobserved factors that can play a role in the sophistication of technologies employed within the firm and the relative demand for female workers, the ordinary least squares (OLS) estimates are likely to be biased. To tackle reverse causality and other endogeneity issues, we estimate (2) using a 2-stage least squares (2SLS) model, with the province-specific ICT quality index being the instrument for ict ${ }_{i t}$, as described in section IV. Specifically, the first stage of our 2SLS specification is

$$
I C T_{i t}=\alpha_{0}+\beta_{0} I C T Q_{r t}+X_{i t} \delta_{0}+\left[F E_{r}+F E_{j}+F E_{t}\right]+\varepsilon_{i t}
$$

The variable ICTQ $r t$ stands for province r's ICT quality in year $t$. The regressors on the righthand side are already defined for equation (2) above. The coefficient on the ICT variable, instrumented by the underlying ICT quality index, captures the effect of using ict on the share of females employed by the marginal firm that increases ICTQ, triggered by improved ICT competitiveness in a province.

\section{EMPIRICAL RESULTS}

\section{A. The Effects of Information and Communication Technology on Female Employment}

Before discussing the 2SLS estimates, we report the OLS estimates of (1) to show the correlation between firms' ICT and shares of female employment. Based on four of the five firms' ICT adoption measures, we find a positive and statistically significant correlation between firms' ICT and female labor share (see Table 3). The only ICT measure for which there is no significant correlation with firms' female labor shares is the indicator for whether the firm has a website or not. The positive correlation is robust after we control for the firm's log sales, log asset, log employment, age, foreign ownership dummy, state ownership dummy, and the host of fixed effects as described in (1). The OLS estimates of ICT are potentially biased as tasks demands, management quality, and readiness to adopt technology are all unobserved factors that are not included in the models. As a result, instrumental variables approach may provide a more accurate estimate of the effects of ICT on female employment.

Table 4 reports the estimates of the 2SLS model described in (1) and (2). Standard errors are clustered at the province level, the level at which the instrument is constructed. In columns 1-5, we use the technical component of the ICT quality as an instrument for the five measures of firms' ICT, while in columns 6-10, we use the average over the five components of province-level ICT indexes. Regardless of which instrument is used, we find a positive and statistically significant effect of a firm's ICT adoption on its female labor share for all five ICT measures. Specifically, according to the coefficient on $I C T_{\text {ict }}$ in column 1, a 10\% increase in the number of PCs connected to the Internet per worker increases the female labor share of the firm by 3 percentage points. The effect of LAN is larger. According to the coefficient on ICT in column 2, a 10\% increase in the number of PCs connected to LAN per worker increases the female labor share of the firm by 3.5 percentage points. Based on the coefficients on various dummies, columns 3-5 show that compared to firms sharing similar characteristics within the same region, industry, and year that did not adopt those technologies, a firm's adoption of Internet, LAN, and hosting a website are associated with 15, 14, and 30 percentage point higher female labor share. Quantitatively similar results are obtained in columns 6-10 when a more holistic measure of the ICT quality index is used as an instrument. The coefficients on the instruments, as reported in the lower part of Table 4, are all positive and statistically significant. The corresponding Kleibergen-Paap F statistics of the first stage of the 2SLS model, which are significantly 
above 10 (the "rule of thumb" cutoff proposed by Stock and Yogo [2005]), suggest that our instruments pass the weak instrument test. ${ }^{14}$ As the 2SLS estimates are higher than the OLS estimates for all ICT indicators, could be indicative of the marginal firm changing subsequent tasks demands that more explicitly favor females as a result of adoption of ICT due to improvements in the infrastructure. The absence of detailed controls on the current level of occupational task demands therefore would make the OLS estimates downward biased relative to the 2 SLS estimates.

\section{Table 3: Firms' Female Labor Shares and Adoption of Information and Communication} Technology (Ordinary Least Squares)

\begin{tabular}{|c|c|c|c|c|c|}
\hline \multirow{2}{*}{$\begin{array}{l}\text { Dependent Variable } \\
\text { Firm-Level of ICT } \\
\text { Adoption (ICT) }\end{array}$} & \multicolumn{5}{|c|}{ Firm's Female Labor Share } \\
\hline & $\begin{array}{c}\text { (1) } \\
\text { Log } \\
\text { (No. of PCs } \\
\text { with Internet/ } \\
\text { worker) }\end{array}$ & $\begin{array}{c}\text { (2) } \\
\text { Log } \\
\text { (No. of PCs } \\
\text { with LAN/ } \\
\text { worker) }\end{array}$ & $\begin{array}{c}\text { (3) } \\
\text { Dummy } \\
\text { (has Internet } \\
\text { access) }\end{array}$ & $\begin{array}{c}(4) \\
\text { Dummy } \\
\text { (has LAN) }\end{array}$ & $\begin{array}{c}(5) \\
\text { Dummy } \\
\text { (has website) }\end{array}$ \\
\hline ICT & $\begin{array}{l}0.201^{* * *} \\
(0.047)\end{array}$ & $\begin{array}{c}0.144^{* * *} \\
(0.041)\end{array}$ & $\begin{array}{c}0.029^{* * *} \\
(0.007)\end{array}$ & $\begin{array}{l}0.023^{* *} \\
(0.010)\end{array}$ & $\begin{array}{r}0.013 \\
(0.016)\end{array}$ \\
\hline Log (revenue) & $\begin{array}{r}-0.013 \\
(0.009)\end{array}$ & $\begin{array}{r}-0.013 \\
(0.009)\end{array}$ & $\begin{array}{r}-0.012 \\
(0.009)\end{array}$ & $\begin{array}{r}-0.012 \\
(0.009)\end{array}$ & $\begin{array}{r}-0.012 \\
(0.009)\end{array}$ \\
\hline Log (asset) & $\begin{array}{l}-0.020 \\
(0.014)\end{array}$ & $\begin{array}{l}-0.018 \\
(0.014)\end{array}$ & $\begin{array}{l}-0.017 \\
(0.014)\end{array}$ & $\begin{array}{l}-0.017 \\
(0.014)\end{array}$ & $\begin{array}{l}-0.015 \\
(0.014)\end{array}$ \\
\hline Log (employment) & $\begin{array}{r}0.049 \\
(0.047)\end{array}$ & $\begin{array}{r}0.044 \\
(0.047)\end{array}$ & $\begin{array}{r}0.038 \\
(0.048)\end{array}$ & $\begin{array}{r}0.037 \\
(0.048)\end{array}$ & $\begin{array}{r}0.037 \\
(0.048)\end{array}$ \\
\hline Age & $\begin{array}{r}0.000 \\
(0.000)\end{array}$ & $\begin{array}{r}0.000 \\
(0.000)\end{array}$ & $\begin{array}{c}0.000^{*} \\
(0.000)\end{array}$ & $\begin{array}{r}0.000^{*} \\
(0.000)\end{array}$ & $\begin{array}{l}0.000^{* *} \\
(0.000)\end{array}$ \\
\hline Foreign dummy & $\begin{array}{l}0.103^{* * *} \\
(0.008)\end{array}$ & $\begin{array}{l}0.107^{* * *} \\
(0.009)\end{array}$ & $\begin{array}{l}0.114^{* * *} \\
(0.008)\end{array}$ & $\begin{array}{l}0.113^{* * *} \\
(0.008)\end{array}$ & $\begin{array}{l}0.117^{* * *} \\
(0.008)\end{array}$ \\
\hline SOE dummy & $\begin{array}{r}0.017 \\
(0.028)\end{array}$ & $\begin{array}{r}0.021 \\
(0.028)\end{array}$ & $\begin{array}{r}0.020 \\
(0.028)\end{array}$ & $\begin{array}{r}0.021 \\
(0.028)\end{array}$ & $\begin{array}{r}0.021 \\
(0.027)\end{array}$ \\
\hline Year fixed effect & V & $\checkmark$ & $\checkmark$ & v & V \\
\hline Sector fixed effect & $\sqrt{ }$ & $\sqrt{ }$ & $\sqrt{ }$ & $\sqrt{ }$ & $\sqrt{ }$ \\
\hline Region fixed effect & $\sqrt{ }$ & $\sqrt{ }$ & $\sqrt{ }$ & $\sqrt{ }$ & $\sqrt{ }$ \\
\hline No. of Obs & 193,769 & 188,317 & 184,328 & 177,267 & 168,382 \\
\hline R-squared & 0.274 & 0.268 & 0.265 & 0.263 & 0.260 \\
\hline
\end{tabular}

ICT = information and communication technology, LAN = local area network, PC = personal computer, $\mathrm{SOE}=$ state-owned enterprise. Notes: Standard errors, clustered at the sector level, are reported in parentheses. Two-digit sector (11) and region (8) fixed effects are always included. ${ }^{* *} p<0.01,{ }^{* *} p<0.05,{ }^{*} p<0.1$.

Source: Annual Enterprise Census by the General Statistics Office of Viet Nam.

The empirical results support our hypothesis that the rise of nonroutine, interactive type tasks that complement ICT have increased the relative proportion of females employed within firms.

14 The problem of weak instruments is generally less of a concern in this case as the model is just identified since only one instrument is used at a time. 
Table 4: Firms' Female Labor Shares and Adoption of Information and Communication Technology (Two-Stage Least Squares)

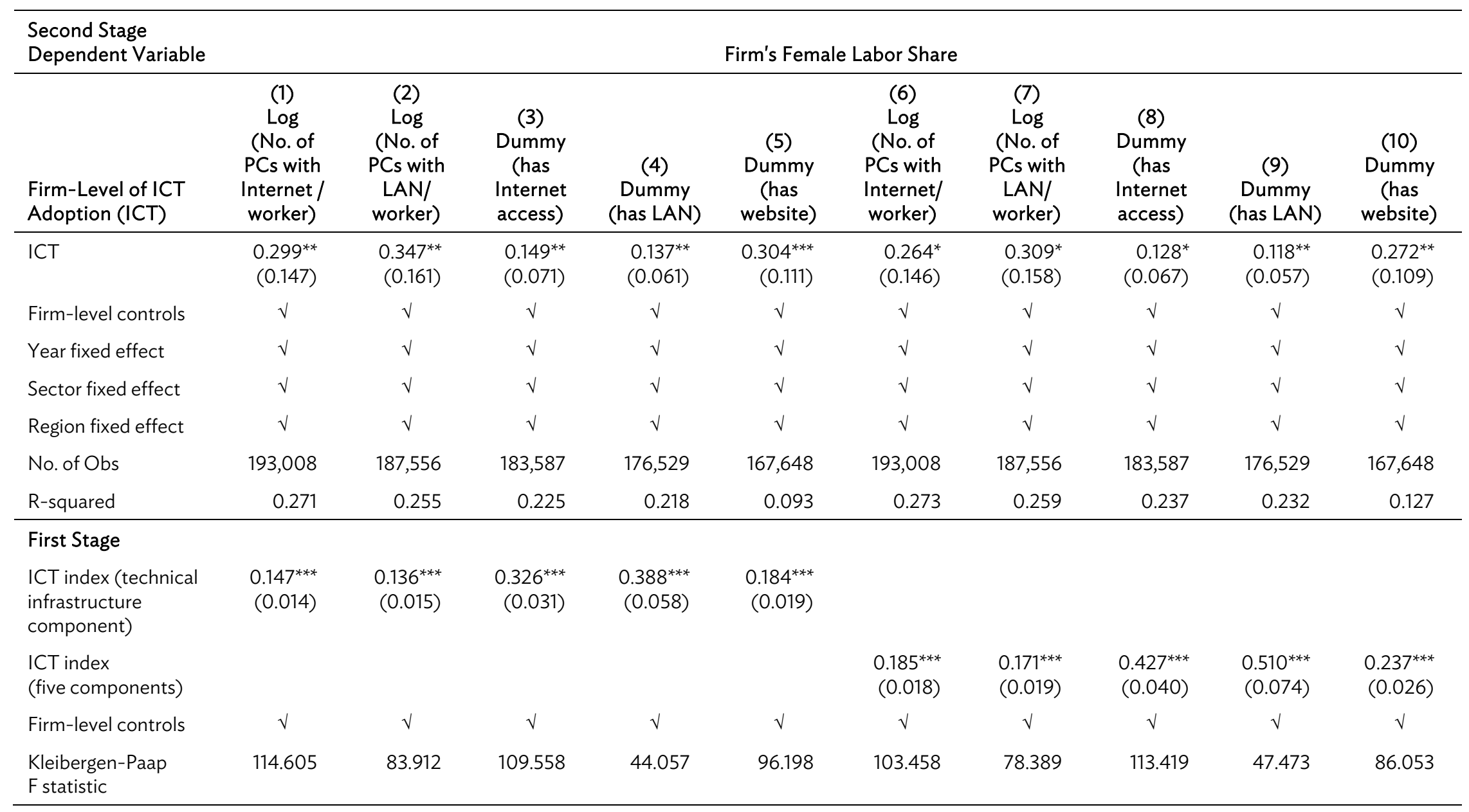

$\mathrm{ICT}=$ information and communication technology, $\mathrm{LAN}=$ local area network, $\mathrm{PC}=$ personal computer.

Notes: Standard errors, clustered at the sector level, are reported in parentheses. ${ }^{* * *} p<0.01,{ }^{* *} p<0.05,{ }^{*} p<0.1$ All coefficients are estimated using the two-stage least squares method, with the first stage having each of the firm's ICT variables as the dependent variable, and province-year-specific ICT index, as described in detail in Appendix Table A.6, as the instrument. Columns (1)-(5) use the index that captures the technical infrastructure aspect of ICT as an instrument in the first stage. Columns (6)-(10) use the index that is a weighted average of five aspects of ICT, including (i) technical infrastructure, (ii) human infrastructure, (iii) applications, (iv) manufacturing business index, and (v) organization/policy environment. Firm-level controls, as reported in Table 3, are always included (but with results suppressed to save space) in both stages of each regression.

Source: Annual Enterprise Census by the General Statistics Office of Viet Nam. 


\section{B. The Effects of Information and Communication Technology on Skilled Employment}

Existing research has consistently shown that ICT complements interactive, complex tasks. For instance, a seminal paper by Autor, Levy, and Murnane (2003) showed that within industries, occupations, and education groups in the US, computerization has reduced the demand for nonroutine, manual, and physical tasks, but increased the demand for nonroutine interactive and highly analytical tasks (e.g., communication-intensive tasks). To the extent that ICT is more likely to replace codifiable tasks, we should expect that the demand for college-educated workers, who have a comparative advantage in nonroutine cognitive tasks, should increase.

In Table 5, we repeat the same exercises as in Table 4, but with the dependent variable replaced by the share of college-educated workers in a firm's total employment. Using our 2SLS model with the province-specific ICT quality as an instrument, we find within a region, sector, and year, a statistically significant and positive effect of firm's ICT on the share of skilled employment. The results are economically significant. For instance, according to the coefficient on ICT in column 1, a 10\% increase in the number of PCs connected to the Internet per worker increases the college-educated labor share of the firm by about 8 percentage points. This is a large increase given that collegeeducated labor only accounts for about $15 \%$ of all labor within the firms in our sample. The quantitative effect of the same percentage increase in the number of computers connected to LAN is about 9 percentage points. Columns 3-5 show that a firm's adoption of LAN, Internet, and hosting a website are associated with 35, 54, and 65 percentage point higher college-educated labor share, respectively, compared to firms sharing similar observable characteristics and operating in the same region, industry, and year that did not adopt those technologies. The results remain robust and quantitatively similar when a more holistic measure of ICT quality index is used as an instrument in columns 6-10.

In Table 6, we replace the dependent variable by the share of female workers in collegeeducated employment of the firm and repeat the same exercises as in Table 4. Our instrumental variable regressions show that within a region, sector, and year, a firm's ICT adoption has a positive and significant effect on the share of women in the firms' college-educated employment. The effects are economically significant. For instance, the coefficient on ICT in column 1 suggests that a $10 \%$ increase in the number of PCs connected to the Internet per worker increases the female share in collegeeducated employment of the firm by about 8 percentage points. The quantitative effect of the same percentage increase in broadband Internet is about 9 percentage points. Columns 3-5 show that a firm's adoption of LAN, Internet, and hosting a website are associated with 31, 46, and 69 percentage point higher female labor share in firms' college-educated employment, respectively, compared to firms with similar observable characteristics and within the same region, industry, and year that did not adopt those technologies. Once again, the results remain robust and quantitatively similar when we use a more holistic measure of ICT quality index as an instrument in columns 6-10.

In sum, ICT increases not only firms' skilled labor share, as has been highlighted in the literature, but also their female share in skilled employment and thus female skilled labor share in total employment. 
Table 5: Firms' Colleged-Educated Labor Shares and Information and Communication Technology Adoption (Two-Stage Least Squares)

\begin{tabular}{|c|c|c|c|c|c|c|c|c|c|c|}
\hline $\begin{array}{l}\text { Second Stage } \\
\text { Dependent Variable }\end{array}$ & \multicolumn{10}{|c|}{ Firm's Share of College Educated Workers } \\
\hline $\begin{array}{l}\text { Firm-Level of ICT } \\
\text { Adoption (ICT) }\end{array}$ & $\begin{array}{c}\text { (1) } \\
\text { Log } \\
\text { (No. of } \\
\text { PCs with } \\
\text { Internet/ } \\
\text { worker) }\end{array}$ & $\begin{array}{c}\text { (2) } \\
\text { Log } \\
\text { (No. of } \\
\text { PCs with } \\
\text { LAN/ } \\
\text { worker) }\end{array}$ & $\begin{array}{l}\text { (3) } \\
\text { Dummy } \\
\text { (has } \\
\text { Internet } \\
\text { access) }\end{array}$ & $\begin{array}{c}\text { (4) } \\
\text { Dummy } \\
\text { (has LAN) }\end{array}$ & $\begin{array}{l}\text { (5) } \\
\text { Dummy } \\
\text { (has } \\
\text { website) }\end{array}$ & $\begin{array}{c}\text { (6) } \\
\text { Log } \\
\text { (No. of } \\
\text { PCs with } \\
\text { Internet/ } \\
\text { worker) }\end{array}$ & $\begin{array}{c}\text { (7) } \\
\text { Log } \\
\text { (No. of } \\
\text { PCs with } \\
\text { LAN/ } \\
\text { worker) }\end{array}$ & $\begin{array}{l}\text { (8) } \\
\text { Dummy } \\
\text { (has } \\
\text { Internet } \\
\text { access) }\end{array}$ & $\begin{array}{c}\text { (9) } \\
\text { Dummy } \\
\text { (has LAN) }\end{array}$ & $\begin{array}{l}\text { (10) } \\
\text { Dummy } \\
\text { (has } \\
\text { website) }\end{array}$ \\
\hline ICT & $\begin{array}{l}0.835^{* *} \\
(0.321)\end{array}$ & $\begin{array}{l}0.943^{* * *} \\
(0.346)\end{array}$ & $\begin{array}{c}0.540^{* * *} \\
(0.192)\end{array}$ & $\begin{array}{c}0.351^{* * *} \\
(0.119)\end{array}$ & $\begin{array}{l}0.646^{* *} \\
(0.306)\end{array}$ & $\begin{array}{l}1.064^{* * *} \\
(0.245)\end{array}$ & $\begin{array}{l}1.193^{* * *} \\
(0.263)\end{array}$ & $\begin{array}{c}0.648^{* * *} \\
(0.161)\end{array}$ & $\begin{array}{l}0.416^{* * *} \\
(0.093)\end{array}$ & $\begin{array}{r}0.854^{* * *} \\
(0.261)\end{array}$ \\
\hline Firm-level controls & $\sqrt{ }$ & $\sqrt{ }$ & $\sqrt{ }$ & $\sqrt{ }$ & $\sqrt{ }$ & $\sqrt{ }$ & $\sqrt{ }$ & $\sqrt{ }$ & $\sqrt{ }$ & $\sqrt{ }$ \\
\hline Year fixed effect & $\sqrt{ }$ & $\sqrt{ }$ & $\sqrt{ }$ & $\sqrt{ }$ & $\sqrt{ }$ & $\sqrt{ }$ & $\sqrt{ }$ & $\sqrt{ }$ & $\sqrt{ }$ & $\sqrt{ }$ \\
\hline Sector fixed effect & $\sqrt{ }$ & $\sqrt{ }$ & $\sqrt{ }$ & $\sqrt{ }$ & $\sqrt{ }$ & $\sqrt{ }$ & $\sqrt{ }$ & $\sqrt{ }$ & $\sqrt{ }$ & $\sqrt{ }$ \\
\hline Region fixed effect & $\sqrt{ }$ & $\sqrt{ }$ & $\sqrt{ }$ & $\sqrt{ }$ & $\sqrt{ }$ & $\sqrt{ }$ & $\sqrt{ }$ & $\sqrt{ }$ & $\sqrt{ }$ & $\sqrt{ }$ \\
\hline No. of Obs & 93,850 & 91,389 & 90,815 & 87,521 & 82,258 & 93,850 & 91,389 & 90,815 & 87,521 & 82,258 \\
\hline R-squared & 0.064 & -0.017 & -0.571 & -0.262 & -0.757 & -0.039 & -0.174 & -0.911 & -0.454 & -1.481 \\
\hline \multicolumn{11}{|l|}{ First Stage } \\
\hline $\begin{array}{l}\text { ICT index (technical } \\
\text { infrastructure } \\
\text { component) }\end{array}$ & $\begin{array}{l}0.153^{* * *} \\
(0.039)\end{array}$ & $\begin{array}{l}0.138^{* * *} \\
(0.039)\end{array}$ & $\begin{array}{l}0.221^{* * *} \\
(0.022)\end{array}$ & $\begin{array}{l}0.349^{* * *} \\
(0.063)\end{array}$ & $\begin{array}{l}0.186^{* * *} \\
(0.042)\end{array}$ & & & & & \\
\hline $\begin{array}{l}\text { ICT index } \\
\text { (five components) }\end{array}$ & & & & & & $\begin{array}{l}0.199^{* * *} \\
(0.048)\end{array}$ & $\begin{array}{l}0.180^{* * *} \\
(0.049)\end{array}$ & $\begin{array}{l}0.311^{* * *} \\
(0.035)\end{array}$ & $\begin{array}{l}0.495^{* * *} \\
(0.078)\end{array}$ & $\begin{array}{l}0.243^{* * *} \\
(0.055)\end{array}$ \\
\hline Firm-level controls & $\sqrt{ }$ & $\sqrt{ }$ & $\sqrt{ }$ & $\sqrt{ }$ & $\sqrt{ }$ & $\sqrt{ }$ & $\sqrt{ }$ & $\sqrt{ }$ & $\sqrt{ }$ & $\sqrt{ }$ \\
\hline $\begin{array}{l}\text { Kleibergen-Paap } \\
\text { F statistic }\end{array}$ & 106 & 81.441 & 43.964 & 41.785 & 71.371 & 81.654 & 64.203 & 58.738 & 40.805 & 68.048 \\
\hline
\end{tabular}

ICT = information and communication technology, LAN = local area network, $\mathrm{PC}=$ personal computer.

Notes: Standard errors, clustered at the province level, are reported in parentheses. ${ }^{* *} p<0.01,{ }^{* *} p<0.05,{ }^{*} p<0.1$. All coefficients are estimated using the two-stage least squares method, with the first stage having each of the firm's ICT variables as the dependent variable, and province-year-specific ICT index, as described in detail in Appendix Table A.6, as the instrument. Columns (1)-(5) use the index that captures the technical infrastructure aspect of ICT as an instrument in the first stage. Columns (6)-(10) use the index that is a weighted average of the five aspects of ICT, including (i) technical infrastructure, (ii) human infrastructure, (iii) applications, (iv) manufacturing business index, and (v) organization/policy environment. Firm-level controls, as reported in Table 3, are always included (but with results suppressed to save space) in both stages of each regression.

Source: Annual Enterprise Census by the General Statistics Office of Viet Nam. 
Table 6: Firms' Female Labor Shares among Colleged-Educated Workers and Information and Communication Technology Adoption (Two-Stage Least Squares)

\begin{tabular}{|c|c|c|c|c|c|c|c|c|c|c|}
\hline $\begin{array}{l}\text { Second Stage } \\
\text { Dependent Variable }\end{array}$ & \multicolumn{10}{|c|}{ Firm's Female Labor Share among the College-Educated Workers } \\
\hline $\begin{array}{l}\text { Firm-Level of ICT } \\
\text { Adoption (ICT) }\end{array}$ & $\begin{array}{c}\text { (1) } \\
\text { Log } \\
\text { (No. of } \\
\text { PCs with } \\
\text { Internet/ } \\
\text { worker) }\end{array}$ & $\begin{array}{c}\text { (2) } \\
\text { Log } \\
\text { (No. of } \\
\text { PCs with } \\
\text { LAN/ } \\
\text { worker) }\end{array}$ & $\begin{array}{c}\text { (3) } \\
\text { Dummy } \\
\text { (has } \\
\text { Internet } \\
\text { access) }\end{array}$ & $\begin{array}{c}\text { (4) } \\
\text { Dummy } \\
\text { (has LAN) }\end{array}$ & $\begin{array}{c}\text { (5) } \\
\text { Dummy } \\
\text { (has } \\
\text { website) }\end{array}$ & $\begin{array}{c}\text { (6) } \\
\text { Log } \\
\text { (No. of } \\
\text { PCs with } \\
\text { Internet/ } \\
\text { worker) }\end{array}$ & $\begin{array}{c}\text { (7) } \\
\text { Log } \\
\text { (No. of } \\
\text { PCs with } \\
\text { LAN/ } \\
\text { worker) }\end{array}$ & $\begin{array}{c}\text { (8) } \\
\text { Dummy } \\
\text { (has } \\
\text { Internet } \\
\text { access) }\end{array}$ & $\begin{array}{c}\text { (9) } \\
\text { Dummy } \\
\text { (has LAN) }\end{array}$ & $\begin{array}{c}\text { (10) } \\
\text { Dummy } \\
\text { (has } \\
\text { website) }\end{array}$ \\
\hline ICT & $\begin{array}{c}0.798^{* * *} \\
(0.185)\end{array}$ & $\begin{array}{l}0.896^{* * *} \\
(0.218)\end{array}$ & $\begin{array}{c}0.462^{* * *} \\
(0.091)\end{array}$ & $\begin{array}{l}0.313^{* * *} \\
(0.064)\end{array}$ & $\begin{array}{c}0.688^{* * *} \\
(0.174)\end{array}$ & $\begin{array}{l}0.881^{* * *} \\
(0.177)\end{array}$ & $\begin{array}{l}1.000^{* * *} \\
(0.218)\end{array}$ & $\begin{array}{l}0.484^{* * *} \\
(0.084)\end{array}$ & $\begin{array}{l}0.328^{* * *} \\
(0.066)\end{array}$ & $\begin{array}{r}0.764^{* * *} \\
(0.170)\end{array}$ \\
\hline Firm-level controls & $\sqrt{ }$ & $\sqrt{ }$ & $\sqrt{ }$ & $\sqrt{ }$ & $\sqrt{ }$ & $\sqrt{ }$ & $\sqrt{ }$ & $\sqrt{ }$ & $\sqrt{ }$ & $\sqrt{ }$ \\
\hline Year fixed effect & $\sqrt{ }$ & $\sqrt{ }$ & $\sqrt{ }$ & $\sqrt{ }$ & $\sqrt{ }$ & $\sqrt{ }$ & $\sqrt{ }$ & $\sqrt{ }$ & $\sqrt{ }$ & $\sqrt{ }$ \\
\hline Sector fixed effect & $\sqrt{ }$ & $\sqrt{ }$ & $\sqrt{ }$ & $\sqrt{ }$ & $\sqrt{ }$ & $\sqrt{ }$ & $\sqrt{ }$ & $\sqrt{ }$ & $\sqrt{ }$ & $\sqrt{ }$ \\
\hline Region fixed effect & $\sqrt{ }$ & $\sqrt{ }$ & $\sqrt{ }$ & $\sqrt{ }$ & $\sqrt{ }$ & $\sqrt{ }$ & $\sqrt{ }$ & $\sqrt{ }$ & $\sqrt{ }$ & $\sqrt{ }$ \\
\hline No. of Obs & 57,172 & 56,302 & 54,613 & 52,886 & 49,609 & 57,172 & 56,302 & 54,613 & 52,886 & 49,609 \\
\hline R-squared & 0.081 & 0.038 & -0.106 & -0.016 & -0.340 & 0.064 & 0.008 & -0.132 & -0.034 & -0.457 \\
\hline \multicolumn{11}{|l|}{ First Stage } \\
\hline $\begin{array}{l}\text { ICT index (technical } \\
\text { infrastructure } \\
\text { component) }\end{array}$ & $\begin{array}{l}0.140^{* * *} \\
(0.013)\end{array}$ & $\begin{array}{l}0.128^{* * *} \\
(0.014)\end{array}$ & $\begin{array}{c}0.229^{* * *} \\
(0.031)\end{array}$ & $\begin{array}{l}0.342^{* * *} \\
(0.053)\end{array}$ & $\begin{array}{l}0.160^{* * *} \\
(0.024)\end{array}$ & & & & & \\
\hline $\begin{array}{l}\text { ICT index } \\
\text { (five components) }\end{array}$ & & & & & & $\begin{array}{l}0.177^{* * *} \\
(0.018)\end{array}$ & $\begin{array}{l}0.159^{* * *} \\
(0.021)\end{array}$ & $\begin{array}{l}0.304^{* * *} \\
(0.038)\end{array}$ & $\begin{array}{c}0.454^{* * *} \\
(0.081)\end{array}$ & $\begin{array}{l}0.198^{* * *} \\
(0.030)\end{array}$ \\
\hline Firm-level controls & $\sqrt{ }$ & $\sqrt{ }$ & $\sqrt{ }$ & $\sqrt{ }$ & $\sqrt{ }$ & $\sqrt{ }$ & $\sqrt{ }$ & $\sqrt{ }$ & $\sqrt{ }$ & $\sqrt{ }$ \\
\hline $\begin{array}{l}\text { Kleibergen-Paap } \\
\text { F statistic }\end{array}$ & 115.726 & 79.687 & 55.413 & 41.222 & 45.693 & 97.369 & 56.614 & 65.021 & 31.059 & 43.327 \\
\hline
\end{tabular}

ICT = information and communication technology, LAN = local area network, $\mathrm{PC}=$ personal computer.

Notes: Standard errors, clustered at the province level, are reported in parentheses. ${ }^{* *} p<0.01,{ }^{* *} p<0.05,{ }^{*} p<0.1$. All coefficients are estimated using the two-stage least squares method, with the first stage having each of the firm's ICT variables as the dependent variable, and province-year-specific ICT index, as described in detail in Appendix Table A.6, as the instrument. Columns (1)-(5) use the index that captures the technical infrastructure aspect of ICT as an instrument in the first stage. Columns (6)-(10) use the index that is a weighted average of the five aspects of ICT, including (i) technical infrastructure, (ii) human infrastructure, (iii) applications, (iv) manufacturing business index, and (v) organization/policy environment. Firm-level controls, as reported in Table 3, are always included (but with results suppressed to save space) in both stages of each regression.

Source: Annual Enterprise Census by the General Statistics Office of Viet Nam. 


\section{Differential Effects across Industries}

Next, we examine the differential effects of ICT across industries. The findings in Tables 5 and 6 are consistent with the hypothesis that ICT is complementary to interactive, and more skilled tasks where women potentially have a comparative advantage. As Autor, Levy, and Murnane (2003) show, the tasks that are more substitutable with ICT tend to be routine tasks, that require relatively little interaction and communication between people. Black and Spitz-Oener (2010) show that in Germany, technological change is partly responsible for the rise in firms' demand for nonroutine interactive tasks, for which females have a comparative advantage relative to physical and manual type tasks for which males have a comparative advantage. On the other hand, Lindley (2012) provides suggestive evidence for the United Kingdom that females may have lost ground in highly technical sectors requiring specific education and training. To provide some evidence to support the different channels that could be driving the complementarity between ICT and female labor at the firm level, namely the relative rise of interactive tasks that have occurred in less complex sectors, we examine whether the ICT employment effects differ across industries. To this end, we estimate equation (3) along with an additional interaction term between a sector's characteristic $\left(T_{j}\right)$ and firm-level ICT adoption $\left(I C T_{i t}\right)$ as follows.

$$
\frac{f_{i t}}{l_{i t}}=\alpha+\beta I C T_{i t}+\theta T_{j} * I C T_{i t}+X_{i t} \delta+\left[F E_{r}+F E_{j}+F E_{t}\right]+\omega_{i t}
$$

As described in section V.C, we use a sector (time-invariant) measure of either task complexity, corresponding to the degree to which the industry entails complex problem solving, or manual and physical task intensity. The expected sign of $\beta$ is positive, while that on $\theta$ can be positive or negative, depending on whether female workers are endowed with the skills that complement (or are less substitutable with) ICT. If $T_{j}$ captures an industry's intensity of complex tasks, in which males have a comparative advantage due to their relatively tendency to invest in STEM education and training, as we postulate in Hypothesis 2, we should expect a negative $\theta$. On the other hand, if $T_{j}$ captures an industry's intensity of manual and physical tasks, with which ICT is more substitutable and in which male workers have a comparative advantage, we should expect a positive $\theta$.

Table 7 reports the estimates of (3), using a firm's female employment share as the dependent variable. Using the technical infrastructure component of the ICT index and its interaction with an industry's task complexity as instruments, we find negative and statistically significant coefficients on the interaction terms between each of the five ICT variables and the sectoral measure of complexity in the second stage of the 2SLS model. These results imply that the positive effects of ICT on firms' female employment are on average weaker in industries that are more dependent on complex tasks. This is believed to be driven by the relative scarcity of highly educated females in the labor market to perform more complex tasks. ${ }^{15}$ Existing evidence shows that men have a comparative advantage in physically, intensive tasks, while women have a comparative advantage in communication intensive and non-routine tasks (Guiso et al. 2008). However, in more complex sectors males may have comparative advantages relative to females because of a higher proportion of men trained in highly technical skills (Lindley 2012). Thus, in industries that require higher order technical, problem solving skills, females benefit less from ICT possibly due to having lower levels of technical training. To the extent that complex sectors are more complementary to ICT, but also require more technical skills, these findings show that the types of tasks that have grown in relative importance in terms of

15 While it would be interesting to examine the effects of industry-level interactions with college employment shares, the smaller sample size and variation in the data makes it harder to obtain statistically significant estimates on these effects. 
complexity appears to be an important channel through which ICT complements labor along the gender dimension.

In Table 8, we repeat similar regressions with the $T_{j}$ interaction term replaced by an industryspecific measure to which tasks are nonroutine, manual, and physical. We find that while on average female labor shares are higher in industries requiring more manual and physical tasks, the positive effects of ICT on firms' female employment are smaller in industries that are more dependent on manual and physical tasks. This supports the hypothesis that ICT could be contributing to greater gender inequality in areas that require greater interaction and are less reliant on physical skills. ${ }^{16}$

\section{Table 7: The Differential Effects of Information and Communication Technology on Firms' Female Labor Shares across Industries (Task Complexity)}

\begin{tabular}{|c|c|c|c|c|c|}
\hline $\begin{array}{l}\text { Second Stage } \\
\text { Dependent } \\
\text { Variable }\end{array}$ & \multicolumn{5}{|c|}{ Firm's Female Labor Share } \\
\hline $\begin{array}{l}\text { Firm-Level of ICT } \\
\text { Adoption (ICT) }\end{array}$ & $\begin{array}{c}\text { (1) } \\
\text { Log } \\
\text { (No. of PCs } \\
\text { with Internet/ } \\
\text { worker) }\end{array}$ & $\begin{array}{c}\text { (2) } \\
\text { Log } \\
\text { (No. of PCs with } \\
\text { LAN/ worker) }\end{array}$ & $\begin{array}{c}\text { (3) } \\
\text { Dummy } \\
\text { (has Internet } \\
\text { access) }\end{array}$ & $\begin{array}{c}\text { (4) } \\
\text { Dummy } \\
\text { (has LAN) }\end{array}$ & $\begin{array}{c}\text { (5) } \\
\text { Dummy } \\
\text { (has website) }\end{array}$ \\
\hline ICT & $\begin{array}{c}0.605^{* * *} \\
(0.186)\end{array}$ & $\begin{array}{r}0.753^{* * *} \\
(0.217)\end{array}$ & $\begin{array}{c}0.316^{* * *} \\
(0.115)\end{array}$ & $\begin{array}{c}0.296^{* * *} \\
(0.101)\end{array}$ & $\begin{array}{r}0.532^{* * *} \\
(0.125)\end{array}$ \\
\hline $\begin{array}{l}\text { ICT x Industry } \\
\text { complexity }\end{array}$ & $\begin{array}{r}-1.086^{* * *} \\
(0.374)\end{array}$ & $\begin{array}{c}-1.378^{* * *} \\
(0.504)\end{array}$ & $\begin{array}{c}-0.563^{* *} \\
(0.240)\end{array}$ & $\begin{array}{c}-0.533^{* *} \\
(0.228)\end{array}$ & $\begin{array}{r}-0.899^{* * *} \\
(0.273)\end{array}$ \\
\hline Industry complexity & $\begin{array}{c}-0.373^{* *} \\
(0.155)\end{array}$ & $\begin{array}{c}-0.390^{* *} \\
(0.175)\end{array}$ & $\begin{array}{l}-0.001 \\
(0.170)\end{array}$ & $\begin{array}{r}-0.214 \\
(0.149)\end{array}$ & $\begin{array}{r}-0.440^{* * *} \\
(0.145)\end{array}$ \\
\hline Firm-level controls & $V$ & $\sqrt{ }$ & $\sqrt{ }$ & $\sqrt{ }$ & V \\
\hline Year fixed effect & $\sqrt{ }$ & $\sqrt{ }$ & $\sqrt{ }$ & $\sqrt{ }$ & $\sqrt{ }$ \\
\hline $\begin{array}{l}\text { Industry (2-digit) } \\
\text { fixed effect }\end{array}$ & $\sqrt{ }$ & $\sqrt{ }$ & $\sqrt{ }$ & $\sqrt{ }$ & $\sqrt{ }$ \\
\hline Region fixed effect & $\sqrt{ }$ & $\sqrt{ }$ & $\sqrt{ }$ & $\sqrt{ }$ & $\sqrt{ }$ \\
\hline No. of Obs & 188,446 & 183,188 & 179,376 & 172,559 & 163,863 \\
\hline R-squared & 0.431 & 0.430 & 0.426 & 0.428 & 0.405 \\
\hline \multicolumn{6}{|l|}{ First Stage } \\
\hline $\begin{array}{l}\text { Kleibergen-Paap } \\
\text { F statistic }\end{array}$ & 55.499 & 33.602 & 52.879 & 20.413 & 27.001 \\
\hline \multicolumn{6}{|c|}{$\begin{array}{l}\text { ICT = information and communication technology, LAN = local area network, } P C=\text { personal computer. } \\
\text { Notes: Standard errors, clustered at the province level, are reported in parentheses. }{ }^{* *} p<0.01,{ }^{* *} p<0.05,{ }^{*} p<0.1 \text {. All coefficients are } \\
\text { estimated using the two-stage least squares method, with the first stage having each of the firm's ICT variables as the dependent variable, } \\
\text { and province-year-specific ICT index, as described in detail in Appendix Table A.6, as the instrument. The ICT index used as an instrument } \\
\text { in the first stage captures the technical infrastructure aspect of ICT. Firm-level controls, as reported in Table 3, are always included (but with } \\
\text { results suppressed to save space) in both stages of each regression. } \\
\text { Source: Annual Enterprise Census by the General Statistics Office of Viet Nam. }\end{array}$} \\
\hline
\end{tabular}

16 Interactions with nonroutine tasks along manual and interactive, analytical and cognitive, and analytical and personal by industry were examined. All of the interaction effects between these tasks and ICT had a positive relationship with female employment shares. 


\section{Table 8: The Differential Effects of Information and Communication Technology on Firms' Intensity of Nonroutine, Manual and Physical Tasks}

\begin{tabular}{|c|c|c|c|c|c|}
\hline $\begin{array}{l}\text { Second Stage } \\
\text { Dependent } \\
\text { Variable }\end{array}$ & & & Female Labor & & \\
\hline $\begin{array}{l}\text { Firm-level of ICT } \\
\text { adoption (ICT) }\end{array}$ & $\begin{array}{c}\text { (1) } \\
\text { Log } \\
\text { (No. of PCs } \\
\text { with Internet/ } \\
\text { worker) }\end{array}$ & $\begin{array}{c}\text { (2) } \\
\text { Log } \\
\text { (No. of PCs with } \\
\text { LAN/worker) }\end{array}$ & $\begin{array}{c}\text { (3) } \\
\text { Dummy } \\
\text { (has Internet } \\
\text { access) } \\
\end{array}$ & $\begin{array}{c}\text { (4) } \\
\text { Dummy } \\
\text { (has LAN) }\end{array}$ & $\begin{array}{c}(5) \\
\text { Dummy } \\
\text { (has website) }\end{array}$ \\
\hline $\begin{array}{l}\text { ICT } x \text { Industry } \\
\text { manual and physical } \\
\text { intensity }\end{array}$ & $\begin{array}{l}-0.038 \\
(0.121)\end{array}$ & $\begin{array}{l}-0.109 \\
(0.134)\end{array}$ & $\begin{array}{l}-0.039 \\
(0.047)\end{array}$ & $\begin{array}{l}-0.005 \\
(0.051)\end{array}$ & $\begin{array}{l}-0.030 \\
(0.067)\end{array}$ \\
\hline $\begin{array}{l}\text { ICT } x \text { Industry } \\
\text { manual and physical } \\
\text { intensity }\end{array}$ & $\begin{array}{r}-0.625^{* *} \\
(0.240)\end{array}$ & $\begin{array}{r}-0.895^{* * *} \\
(0.327)\end{array}$ & $\begin{array}{r}-0.293^{* *} \\
(0.125)\end{array}$ & $\begin{array}{r}-0.229^{* *} \\
(0.095)\end{array}$ & $\begin{array}{r}-0.576^{* * *} \\
(0.170)\end{array}$ \\
\hline $\begin{array}{l}\text { Industry manual and } \\
\text { physical intensity }\end{array}$ & $\begin{array}{l}0.413^{* * *} \\
(0.037)\end{array}$ & $\begin{array}{l}0.437^{* * *} \\
(0.036)\end{array}$ & $\begin{array}{l}0.467^{* * *} \\
(0.044)\end{array}$ & $\begin{array}{l}0.499^{* * *} \\
(0.060)\end{array}$ & $\begin{array}{l}0.416^{* * *} \\
(0.043)\end{array}$ \\
\hline Firm-level controls & $v$ & v & v & $v$ & $v$ \\
\hline Year fixed effect & v & V & $\sqrt{ }$ & v & v \\
\hline $\begin{array}{l}\text { Industry (2-digit) } \\
\text { fixed effect }\end{array}$ & $\checkmark$ & $\checkmark$ & $\checkmark$ & $\checkmark$ & v \\
\hline Region fixed effect & v & $\sqrt{ }$ & v & $\sqrt{ }$ & $\checkmark$ \\
\hline No. of Obs & 185,729 & 180,389 & 173,913 & 180,832 & 165,031 \\
\hline R-squared & 0.436 & 0.425 & 0.407 & 0.414 & 0.373 \\
\hline \multicolumn{6}{|l|}{ First Stage } \\
\hline $\begin{array}{l}\text { Kleibergen-Paap } \\
\text { F statistic }\end{array}$ & 49.09 & 38.83 & 16.02 & 42.03 & 33.49 \\
\hline
\end{tabular}

ICT = information and communication technology, LAN = local area network, $\mathrm{PC}=$ personal computer

Notes: Standard errors, clustered at the province level, are reported in parentheses. ${ }^{* *} p<0.01,{ }^{*} p<0.05,{ }^{*} p<0.1$. All coefficients are estimated using the two-stage least squares method, with the first stage having each of the firm's ICT variables as the dependent variable, and province-year-specific ICT index, as described in detail in Appendix Table A.6, as the instrument. The ICT index used as an instrument in the first stage captures the technical infrastructure aspect of ICT. Firm-level controls, as reported in Table 3, are always included (but with results suppressed to save space) in both stages of each regression. Source: Annual Enterprise Census by the General Statistics of Viet Nam.

\section{CONCLUDING REMARKS}

In this paper, we empirically study the effects of firms' investments in ICT on their demand for female and skilled workers. By exploiting the rapid liberalization of the broadband Internet sector between 2006 and 2009 in Viet Nam and using the country's comprehensive enterprise census data, we find that firms' adoption of broadband Internet and other related ICT increased the relative demand for female and highly skilled workers. The positive effect of ICT on firms' female employment is particularly strong among the college-educated employees, but is weaker in industries that are more dependent on complex (nonroutine) tasks. These results are consistent with the hypothesis that the relative rise of interactive tasks in less complex industries for which females have comparative advantages have led to increases in female employment. 
Our findings based on firm survey data show that within firms, changes in labor demand are an important factor in reducing employment inequality along the gender dimension. For policy makers concerned with providing greater opportunities for females to enter the labor market and secure more stable employment in formal sector firms, implementing policies and programs that induce firms' adoption of ICT can potentially stimulate female employment growth. Given the positive effects of ICT on firm efficiency, these type of policies could contribute more to creating quality employment and income generating opportunities for females compared to programs that narrowly focus on females by providing access to capital and training. That said, the weaker effects on firms' female employment in more complex sectors could point to a potentially important area for policy intervention. As complex sectors become increasingly more important and garner higher wages, strategic gender policies that incentivize females to enter STEM education and training may be important for ensuring greater gender equality in employment opportunities over the longer term.

It is worth noting that despite our findings of a positive relationship between firms' female labor share and ICT, within-firm gender wage gap may still persist. It is possible that ICT induces firms to employ more women without increasing their average pay relative to men. Moreover, the use of registered enterprises in this research ignores an important part of the Vietnamese economy that is in the informal sector. Extending the current analysis in these two directions is a promising avenue for future research. 


\section{APPENDIX}

\section{Table A.1: Major Policies that Improve Information and Communication Technology Capability}

\begin{tabular}{ll}
\hline Year & \multicolumn{1}{c}{ Major Events } \\
\hline 2000 & Vietnam Internet Network Information Center established \\
2002 & Start of liberalization of telecommunication industry to foster competition (going from one single state-owned \\
& monopoly) \\
& First time that CDMA technology was used (allow multiple users to use bandwidth) \\
2006 & EVN Telecon enters market and becomes one of the largest CDMA operators. \\
& Ministry of Post and Telecommunications started banning imports of second hand communication technologies. \\
& Decision to expand mobile services to 62 of the poorest districts and to reach universalization of basic \\
& telecommunications services for extreme poverty. \\
& Ministry of Information and Communication was established to replace the Ministry of Post and Telematics - \\
& responsible for policy and regulation. \\
& Mobile broadband technology was deployed - potentially providing new ways to reach a larger set of \\
& customers. \\
& Viet Nam joins the World Trade Organization. 45\% of ICT equipment duty free and another 45\% have tariffs \\
& ranging from 5\%-10\%. \\
& Viet Nam launches Vinasat I allowing information to be transmitted to all regions of the country. \\
& Tariffs for 228 out of 325 ICT products reduced to 0. \\
& September 2009 3G mobile networks based on CDMA technology deployed with four licenses given out. \\
& Another 25 ICT products tariffs reduced to 0. \\
& Another 72 ICT products tariffs reduced to 0.
\end{tabular}

CDMA = code division multiple access, ICT = information and communication technology

Source: Government of Viet Nam's official publications.

Table A.2: Viet Nam Labor Force Statistics by Gender

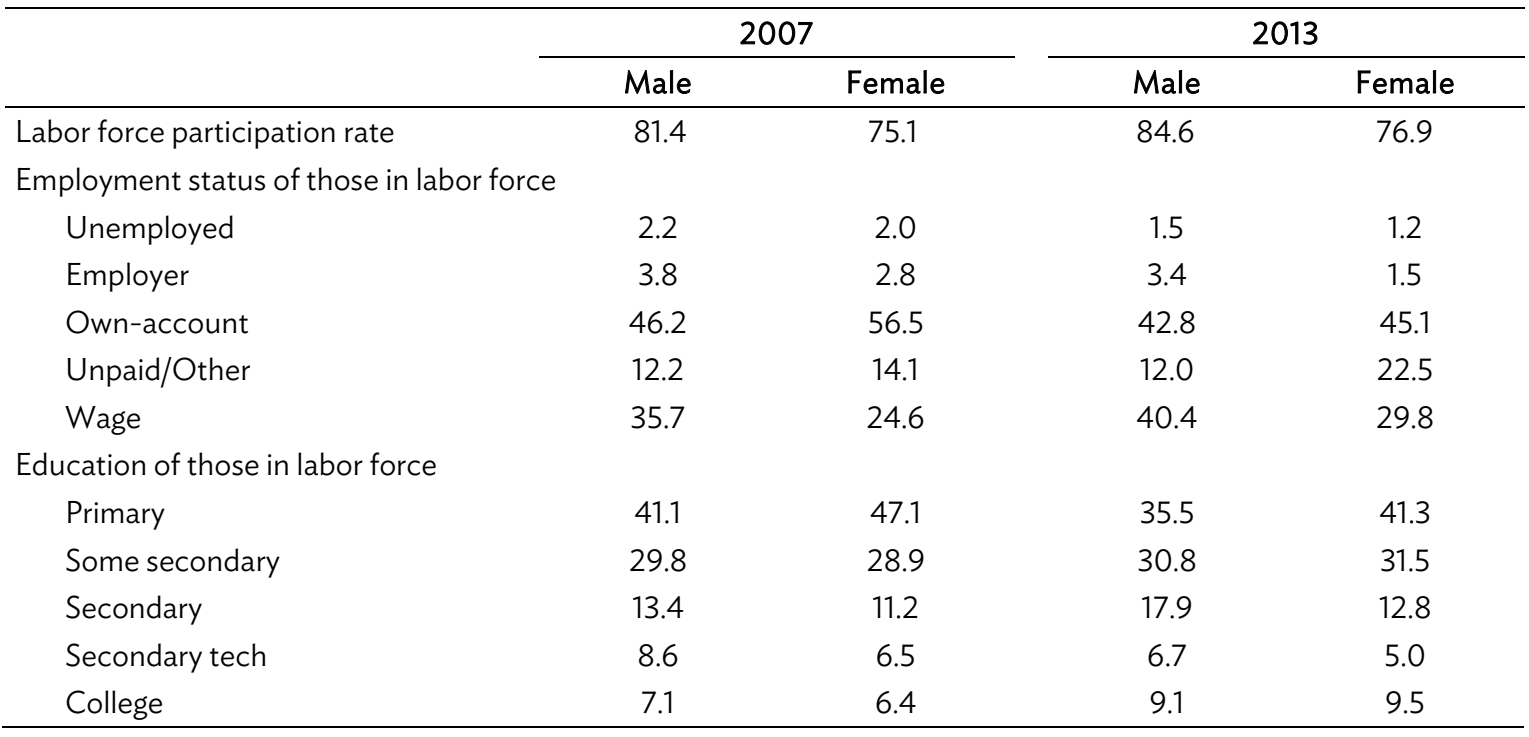

Notes: Statistics based on individuals ages 15-65; Percent values shown.

Source: Viet Nam's Labor Force Surveys. 


\section{Table A.3: Viet Nam Monthly Wages for Wage Workers by Gender and Education}

(\$)

\begin{tabular}{lcccccccc}
\hline & \multicolumn{3}{c}{2007} & & \multicolumn{3}{c}{2013} \\
\cline { 2 - 5 } \cline { 6 - 8 } & Male & Female & Ratio & & Male & Female & Ratio \\
\hline Primary & 1,057 & 769 & 1.37 & & 2,974 & 2,314 & 1.29 \\
Some secondary & 1,044 & 754 & 1.38 & & 3,225 & 2,791 & 1.16 \\
Secondary & 1,249 & 1,055 & 1.18 & & 3,774 & 3,189 & 1.18 \\
Secondary tech & 1,648 & 1,406 & 1.17 & & 4,119 & 3,567 & 1.15 \\
College & 2,537 & 2,085 & 1.22 & & 5,815 & & 4,751 & 1.22 \\
\hline
\end{tabular}

Note: Statistics based on individuals ages 15-65.

Source: Viet Nam's Labor Force Surveys.

Table A.4: Number of Enterprises

\begin{tabular}{lrrrr}
\hline Sector & 2005 & 2006 & 2007 & 2009 \\
\hline Agriculture, forestry and fishing & 1,071 & 583 & 1,477 & 1,585 \\
Mining and quarrying & 711 & 716 & 771 & 926 \\
Manufacturing & 13,481 & 14,665 & 14,773 & 16,372 \\
Construction & 9,061 & 9,489 & 9,806 & 10,804 \\
Wholesale and retail trade & 8,887 & 9,419 & 8,183 & 8,504 \\
Transportation and storage & 2,551 & 2,623 & 3,187 & 3,684 \\
Accommodation and food services & 1,209 & 1,360 & 1,514 & 1,611 \\
Information and communication & 391 & 487 & 482 & 530 \\
Real estate activities & 393 & 468 & 449 & 542 \\
Professional, scientific and technical activities & 1,581 & 1,929 & 1,904 & 1,989 \\
Administrative and support services & 493 & 706 & 735 & 855 \\
\hline
\end{tabular}

Source: Annual Enterprise Census by the General Statistics Office of Viet Nam (2005, 2007-2009) 
Table A.5: Summary Statistics of Viet Nam's Manufacturing Enterprise Surveys

\begin{tabular}{|c|c|c|c|c|c|c|c|c|}
\hline & Short Name & 2005 & 2006 & 2007 & 2008 & 2009 & 2010 & 2011 \\
\hline Number of Obs & & 44,727 & 49,584 & 57,076 & 68,748 & 73,011 & 77,610 & 86,264 \\
\hline $\begin{array}{l}\text { Number of Obs (w/ info } \\
\text { on ICT) }\end{array}$ & & 42,708 & & 46,101 & 48,470 & 52,733 & 51,696 & 80,253 \\
\hline \multirow[t]{2}{*}{ Firm age } & fage & 5.58 & 5.42 & 5.67 & 5.99 & 6.43 & 6.88 & 6.94 \\
\hline & & (19.71) & $(16.40)$ & $(15.50)$ & $(24.98)$ & $(26.45)$ & $(29.46)$ & $(30.44)$ \\
\hline Firm age $<=2$ years & dfage_12 & 0.38 & 0.37 & 0.33 & 0.32 & 0.29 & 0.25 & 0.27 \\
\hline Firm age $3-10$ years & dfage_l10 & 0.49 & 0.51 & 0.54 & 0.55 & 0.58 & 0.6 & 0.57 \\
\hline \multirow[t]{2}{*}{ Profit (2010 VND) } & rtotprf & $3,631.65$ & $4,047.94$ & $4,430.44$ & $2,787.83$ & $4,369.99$ & $3,796.07$ & $2,199.16$ \\
\hline & & $(322,175.00)$ & $(346,716.70)$ & $(290,167.90)$ & $(238,372.00)$ & $(243,731.60)$ & $(207,049.10)$ & $(102,703.60)$ \\
\hline \multirow[t]{2}{*}{ Revenue (2010 VND) } & rtotrev & $67,663.16$ & $66,296.00$ & $71,669.38$ & $62,938.65$ & $69,735.19$ & $75,980.83$ & $76,785.02$ \\
\hline & & $(834,931.40)$ & $(865,657.30)$ & $(857,669.40)$ & $(711,644.40)$ & $(820,762.90)$ & $(930,798.60)$ & $(999,855.50)$ \\
\hline \multirow[t]{2}{*}{ Expenses (2010 VND) } & rtotexp & $64,031.52$ & $62,248.07$ & $67,238.95$ & $60,150.81$ & $65,365.2$ & $72,184.76$ & $74,585.85$ \\
\hline & & $(627,281.60)$ & $(664,734.60)$ & $(701,536.90)$ & $(573,025.00)$ & $(727,795.30)$ & $(858,234.30)$ & $(959,237.40)$ \\
\hline \multirow[t]{2}{*}{ Material expenses (2010 VND) } & rtotmat & $60,087.32$ & $58,542.99$ & $63,200.95$ & $56,695.64$ & $61,400.00$ & $67,971.10$ & $70,601.10$ \\
\hline & & $(613,441.50)$ & $(656,295.00)$ & $(688,747.80)$ & $(564,323.40)$ & $(715,050.40)$ & $(848,844.40)$ & $(949,352.80)$ \\
\hline \multirow[t]{2}{*}{ Wage bill (2010 VND) } & rlaborwage & $3,944.2$ & $3,705.08$ & $4,038.00$ & $3,455.18$ & $3,965.2$ & $4,213.66$ & $3,984.75$ \\
\hline & & $(34,148.66)$ & $(22,805.05)$ & $(36,220.63)$ & $(19,324.90)$ & $(36,536.25)$ & $(27,476.46)$ & $(22,560.55)$ \\
\hline \multirow[t]{2}{*}{ Assets (2010 VND) } & rassets & $54,098.49$ & $51,079.23$ & $59,860.64$ & $49,958.96$ & $69,120.63$ & $84,737.09$ & $58,849.52$ \\
\hline & & $(633,642.40)$ & $(495,105.30)$ & $(761,395.50)$ & $(469,666.70)$ & $(1,269,099.00)$ & $(1,387,491.00)$ & $(672,230.80)$ \\
\hline \multirow[t]{2}{*}{ Labor employed (full-time) } & laborempl & 118.01 & 107.34 & 108.36 & 95.78 & 97.71 & 98.05 & 96.51 \\
\hline & & $(664.19)$ & $(489.72)$ & $(597.81)$ & $(467.53)$ & $(633.77)$ & $(575.46)$ & 0.00 \\
\hline \multirow[t]{2}{*}{ Labor productivity } & laborprod & 763.13 & 788.48 & 871.47 & 925.22 & $1,091.56$ & $1,126.44$ & 947.28 \\
\hline & & $(3,187.30)$ & $(3,492.76)$ & $(4,952.57)$ & $(6,476.49)$ & $(14,857.88)$ & $(10,906.08)$ & $(4,751.13)$ \\
\hline
\end{tabular}


Table A.5 continued

\begin{tabular}{|c|c|c|c|c|c|c|c|c|}
\hline & Short Name & 2005 & 2006 & 2007 & 2008 & 2009 & 2010 & 2011 \\
\hline \multirow[t]{2}{*}{ Labor efficiency } & laboreffi & 29.61 & 28.97 & 30.69 & 29.85 & 31.5 & 29.67 & 29.09 \\
\hline & & $(120.80)$ & (143.31) & $(318.62)$ & $(170.21)$ & $(657.58)$ & $(246.50)$ & (172.12) \\
\hline \multirow[t]{2}{*}{ Female labor share } & shemp_female & 0.32 & 0.33 & 0.33 & 0.32 & 0.32 & 0.33 & 0.34 \\
\hline & & $(0.23)$ & $(0.23)$ & $(0.22)$ & $(0.22)$ & $(0.21)$ & $(0.21)$ & $(0.23)$ \\
\hline \multirow[t]{2}{*}{ College-edu labor share } & shemp_college & & & 0.17 & & 0.09 & & 0.15 \\
\hline & & & & $(0.21)$ & & $(0.20)$ & & $(0.22)$ \\
\hline \multirow{2}{*}{$\begin{array}{l}\text { Female share in college-edu } \\
\text { emp }\end{array}$} & shemp_collegefem & & & 0.35 & & 0.22 & & 0.34 \\
\hline & & & & $(0.31)$ & & $(0.33)$ & & $(0.33)$ \\
\hline Share SOE & dsoe & 0.1 & 0.08 & 0.08 & 0.06 & 0.06 & 0.05 & 0.05 \\
\hline Share FDI & dfdi & 0.07 & 0.07 & 0.07 & 0.07 & 0.07 & 0.07 & 0.07 \\
\hline Import dummy & $\operatorname{dimp}$ & 0.01 & 0.02 & 0.01 & 0.09 & 0.09 & 0.08 & 0.16 \\
\hline Export dummy & dexp & 0.02 & 0.01 & 0.11 & 0.08 & 0.01 & 0.09 & 0.14 \\
\hline
\end{tabular}

$\mathrm{FDI}=$ foreign direct investment, ICT = information and communication technology, $\mathrm{SOE}=$ state-owned enterprise, VND = Viet Nam dong.

Notes: Firms with over 20 employees or above are surveyed. Observations with missing values on revenue, material, or total expenses are dropped. Labor Productivity $=$ Total revenue (2010 VND)

divided by total employment. Labor Efficiency = Total revenue (2010 VND) divided by total wage bill. Sample means of each variable are reported, with standard errors reported in parentheses.

Source: Annual Enterprise Census by the General Statistics Office of Viet Nam. 


\title{
Table A.6: Five Different Aspects of Information and Communication Technology Quality
}

\author{
(a) Technical Infrastructure Index
}

\begin{tabular}{|c|c|c|c|c|c|c|c|c|c|c|}
\hline No & Subindicators & 2005 & 2006 & 2007 & 2009 & 2010 & 2011 & 2012 & 2013 & 2014 \\
\hline 1 & $\begin{array}{l}\text { Number of fixed } \\
\text { telephones per } 100 \\
\text { inhabitants }\end{array}$ & $x$ & $x$ & $x$ & $x$ & $x$ & $x$ & $x$ & $x$ & $x$ \\
\hline 2 & $\begin{array}{l}\text { Number of mobile phones } \\
\text { per } 100 \text { inhabitants }\end{array}$ & $x$ & $x$ & $x$ & $x$ & $x$ & $x$ & $x$ & $x$ & $x$ \\
\hline 3 & $\begin{array}{l}\text { Number of Internet } \\
\text { accounts per } 100 \\
\text { inhabitants }\end{array}$ & $x$ & $x$ & $x$ & $x$ & $x$ & $x$ & $x$ & $x$ & $x$ \\
\hline 4 & $\begin{array}{l}\text { Number of broadband } \\
\text { subscribers (ADSL) per } \\
1,000 \text { households }\end{array}$ & $x$ & $x$ & $x$ & $x$ & & & & & \\
\hline 5 & $\begin{array}{l}\text { Total local connection } \\
\text { bandwith per user }\end{array}$ & $x$ & $x$ & $x$ & & & & & & \\
\hline 6 & $\begin{array}{l}\text { Total connection bandwith } \\
\text { (cross cities and } \\
\text { international) per user }\end{array}$ & $x$ & $x$ & $x$ & & & & & & \\
\hline 7 & $\begin{array}{l}\text { Number of computers per } \\
\text { household }\end{array}$ & $x$ & $x$ & $x$ & $x$ & $x$ & $x$ & $x$ & $x$ & $x$ \\
\hline 8 & $\begin{array}{l}\text { Percentage of households } \\
\text { having broadband Internet } \\
\text { access }\end{array}$ & $x$ & $x$ & $x$ & $x$ & $x$ & $x$ & $x$ & $x$ & $x$ \\
\hline 9 & $\begin{array}{l}\text { Number of computers per } \\
\text { government officer }\end{array}$ & $x$ & $x$ & $x$ & $x$ & & & & & \\
\hline 10 & $\begin{array}{l}\text { Percentage of computers } \\
\text { with Internet access in } \\
\text { public agencies at } \\
\text { provincial level }\end{array}$ & $x$ & $x$ & $x$ & $x$ & & & & & \\
\hline 11 & $\begin{array}{l}\text { Percentage of public } \\
\text { agencies having broadband } \\
\text { Internet access }\end{array}$ & & $x$ & $x$ & & & & & & \\
\hline 12 & $\begin{array}{l}\text { Percentage of enterprises } \\
\text { having broadband Internet } \\
\text { access }\end{array}$ & & $x$ & $x$ & $x$ & $x$ & $x$ & $x$ & $x$ & $x$ \\
\hline 13 & $\begin{array}{l}\text { Percentage of computers } \\
\text { per person among } \\
\text { enterprises }\end{array}$ & & & $x$ & $x$ & $x$ & $x$ & & & \\
\hline 14 & $\begin{array}{l}\text { Percentage of investment in } \\
\text { ICT infrastructure per } \\
\text { capita in 2005, 2006, } 2007\end{array}$ & & & $x$ & $x$ & & & & & \\
\hline 15 & $\begin{array}{l}\text { Percentage of investment } \\
\text { in ICT infrastructure per } \\
\text { capita in } 2007\end{array}$ & & & $x$ & $x$ & & & & & \\
\hline 16 & $\begin{array}{l}\text { Percentage of households } \\
\text { having TV }\end{array}$ & & & & $x$ & $x$ & $x$ & $x$ & $x$ & $x$ \\
\hline
\end{tabular}




\section{8 | Appendix}

Table A.6 continued

\begin{tabular}{|c|c|c|c|c|c|c|c|c|c|c|}
\hline No & Subindicators & 2005 & 2006 & 2007 & 2009 & 2010 & 2011 & 2012 & 2013 & 2014 \\
\hline 17 & $\begin{array}{l}\text { Percentage of broadband } \\
\text { subscribers/100 dân }\end{array}$ & & & & & $x$ & $x$ & $x$ & $x$ & $x$ \\
\hline 18 & $\begin{array}{l}\text { Percentage of fixed } \\
\text { telephones }\end{array}$ & & & & & $x$ & $x$ & $x$ & & $x$ \\
\hline 19 & $\begin{array}{l}\text { Percentage of computers } \\
\text { per official staff in state } \\
\text { agencies at province level }\end{array}$ & & & & & $x$ & $x$ & $x$ & & \\
\hline 20 & $\begin{array}{l}\text { Percentage of computers } \\
\text { in manager public agencies } \\
\text { at provincial level having } \\
\text { broadband Internet access }\end{array}$ & & & & & $x$ & $x$ & & & \\
\hline 21 & $\begin{array}{l}\text { Percentage of computers in } \\
\text { public agencies at province } \\
\text { level having specific Internet } \\
\text { network or Nation (CPNet) }\end{array}$ & & & & & & $x$ & $x$ & $x$ & $x$ \\
\hline 22 & $\begin{array}{l}\text { Percentage of computers per } \\
\text { official staff at province level }\end{array}$ & & & & & & & & $x$ & $x$ \\
\hline 23 & $\begin{array}{l}\text { Percentage of computers } \\
\text { in public agencies at } \\
\text { province level having } \\
\text { broadband Internet access }\end{array}$ & & & & & & & $x$ & $x$ & $x$ \\
\hline 24 & $\begin{array}{l}\text { Percentage of computers } \\
\text { per staff in enterprise }\end{array}$ & & & & & & & $x$ & $x$ & $x$ \\
\hline 25 & $\begin{array}{l}\text { Deployment of information } \\
\text { systems security and data } \\
\text { safety }\end{array}$ & & & & & & & $x$ & $x$ & $x$ \\
\hline 26 & $\begin{array}{l}\text { Percentage of public } \\
\text { agencies at province level } \\
\text { having large-scale Internet }\end{array}$ & & & & & & & $x$ & $x$ & $x$ \\
\hline \multicolumn{2}{|c|}{ Number of criteria by year } & 10 & 12 & 15 & 13 & 12 & 13 & 15 & 15 & 15 \\
\hline
\end{tabular}

ADSL = asymmetric digital subscriber line, ICT = information and communication technology.

Source: Authors' computation based on the Government of Viet Nam's official publications.

(b) Human Infrastructure Index

\begin{tabular}{|c|c|c|c|c|c|c|c|c|c|c|}
\hline No & Subindicators & 2005 & 2006 & 2007 & 2009 & 2010 & 2011 & 2012 & 2013 & 2014 \\
\hline 1 & $\begin{array}{l}\text { Number of literate people } \\
\text { per } 100 \text { inhabitants }\end{array}$ & $x$ & & & & & & & & \\
\hline 2 & $\begin{array}{l}\text { Number of official } \\
\text { education and training } \\
\text { facilities (university, } \\
\text { college, technical) per } \\
100,000 \text { inhabitants }\end{array}$ & $x$ & $x$ & $x$ & & & & & & \\
\hline 3 & $\begin{array}{l}\text { Number of graduates from } \\
\text { official education and } \\
\text { training facilities in } 2005 \\
\text { per } 1,000 \text { inhabitants }\end{array}$ & $x$ & $x$ & $x$ & & & & & & \\
\hline
\end{tabular}


Table A. 6 continued

\begin{tabular}{|c|c|c|c|c|c|c|c|c|c|c|}
\hline No & Subindicators & 2005 & 2006 & 2007 & 2009 & 2010 & 2011 & 2012 & 2013 & 2014 \\
\hline 4 & $\begin{array}{l}\text { Number of unofficial } \\
\text { education and training } \\
\text { facilities in IT per 100,000 } \\
\text { inhabitants }\end{array}$ & $x$ & $x$ & $x$ & & & & & & \\
\hline 5 & $\begin{array}{l}\text { Number of graduates from } \\
\text { official education and } \\
\text { training facilities in IT in } \\
2005 \text { per } 1,000 \text { inhabitants }\end{array}$ & $x$ & $x$ & $x$ & & & & & & \\
\hline 6 & $\begin{array}{l}\text { Number of people working } \\
\text { in ICT industry per } 100 \\
\text { inhabitants }\end{array}$ & $x$ & & & & & & & & \\
\hline 7 & $\begin{array}{l}\text { Number of people with at } \\
\text { least college degree in ICT }\end{array}$ & $x$ & & & & & & & & \\
\hline 8 & $\begin{array}{l}\text { Percentage of primary } \\
\text { school teaching } \\
\text { computerization }\end{array}$ & & $x$ & $x$ & $x$ & $x$ & $x$ & $x$ & $x$ & $x$ \\
\hline 9 & $\begin{array}{l}\text { Percentage of secondary } \\
\text { school teaching } \\
\text { computerization }\end{array}$ & & $x$ & $x$ & $x$ & $x$ & $x$ & $x$ & $x$ & $x$ \\
\hline 10 & $\begin{array}{l}\text { Percentage of high school } \\
\text { teaching computerization }\end{array}$ & & $x$ & $x$ & $x$ & $x$ & $\mathrm{x}$ & $x$ & $x$ & $x$ \\
\hline 11 & $\begin{array}{l}\text { Percentage of official staff } \\
\text { in public agencies at } \\
\text { province level know to using } \\
\text { computer in their work }\end{array}$ & & $x$ & $x$ & $x$ & $x$ & $x$ & $x$ & $x$ & $x$ \\
\hline 12 & $\begin{array}{l}\text { Percentage of IT staff in } \\
\text { charge of the state } \\
\text { management agencies at } \\
\text { provinces level }\end{array}$ & & & $x$ & $x$ & $x$ & $x$ & $x$ & $x$ & $x$ \\
\hline 13 & $\begin{array}{l}\text { Percentage budget for IT } \\
\text { training per person in } 3 \\
\text { years }(2005,2006,2007)\end{array}$ & & & $x$ & & & & & & \\
\hline 14 & $\begin{array}{l}\text { Percentage budget for IT } \\
\text { training per person in } 2007 \\
\text { and } 2008\end{array}$ & & & $x$ & $x$ & & & & & \\
\hline 15 & $\begin{array}{l}\text { Percentage of official staff } \\
\text { in public agencies training, } \\
\text { guiding to using open } \\
\text { software }\end{array}$ & & & & & & $x$ & $x$ & $x$ & $x$ \\
\hline 16 & $\begin{array}{l}\text { Percentage of university, } \\
\text { college at provincial having } \\
\text { specialized training IT }\end{array}$ & & & & & & & $x$ & $x$ & $x$ \\
\hline 17 & $\begin{array}{l}\text { Percentage of staff in charge } \\
\text { of information security at } \\
\text { province's state agencies }\end{array}$ & & & & & & & $x$ & $x$ & $x$ \\
\hline \multicolumn{2}{|c|}{ Number of criteria by year } & 7 & 8 & 11 & 6 & 5 & 6 & 8 & 8 & 8 \\
\hline
\end{tabular}

$\mathrm{ICT}$ = information and communication technology, IT = information technology.

Source: Authors' computation based on the Government of Viet Nam's official publications 
30 | Appendix

Table A.6 continued

(c) Information and Communication Technology Applications Index

\begin{tabular}{|c|c|c|c|c|c|c|c|c|c|c|}
\hline No & Subindicators & 2005 & 2006 & 2007 & 2009 & 2010 & 2011 & 2012 & 2013 & 2014 \\
\hline 1 & $\begin{array}{l}\text { Number of local phone } \\
\text { calls per capita }\end{array}$ & $x$ & $x$ & $x$ & & & & & & \\
\hline 2 & $\begin{array}{l}\text { Number of cross-city and } \\
\text { international phone call per } \\
\text { capita }\end{array}$ & $x$ & $x$ & $x$ & & & & & & \\
\hline 3 & Budget for ICT per capita & $x$ & $x$ & $x$ & & & & & & \\
\hline 4 & $\begin{array}{l}\% \text { public agencies having } \\
\text { Internet access }\end{array}$ & $x$ & & & & & & & & \\
\hline 5 & $\begin{array}{l}\% \text { enterprises having } \\
\text { Internet access }\end{array}$ & $x$ & & & & & & & & \\
\hline 6 & $\begin{array}{l}\% \text { public agencies having } \\
\text { official websites }\end{array}$ & $x$ & $x$ & & & & & & & \\
\hline 7 & $\begin{array}{l}\% \text { enterprises having } \\
\text { official websites }\end{array}$ & $x$ & $x$ & $x$ & $x$ & $x$ & & $x$ & $x$ & $x$ \\
\hline 8 & $\begin{array}{l}\% \text { staff granted official } \\
\text { email of province, city and } \\
\text { using email in their work }\end{array}$ & & & & & & $x$ & $x$ & $x$ & $x$ \\
\hline 9 & $\begin{array}{l}\text { Computerization of } \\
\text { administrative procedures }\end{array}$ & & & & & $x$ & $x$ & $x$ & $x$ & $x$ \\
\hline 10 & $\begin{array}{l}\text { Implement the basic } \\
\text { application }\end{array}$ & & & & & $x$ & $x$ & $x$ & $x$ & $x$ \\
\hline 11 & $\begin{array}{l}\text { Build of the specialized } \\
\text { databases }\end{array}$ & & & & & & & $x$ & $x$ & $x$ \\
\hline 12 & $\begin{array}{l}\text { Apply to open source } \\
\text { software }\end{array}$ & & & & & & $x$ & $x$ & $x$ & $x$ \\
\hline 13 & Use electronic documents & & & & & & & $x$ & $x$ & $x$ \\
\hline 14 & Website of province/city & & $x$ & $x$ & & $x$ & $x$ & $x$ & $x$ & $x$ \\
\hline 15 & $\begin{array}{l}\text { Implement public services } \\
\text { online }\end{array}$ & & & & & & & $x$ & $x$ & $x$ \\
\hline 16 & $\begin{array}{l}\% \text { official staff granted } \\
\text { official email of province, } \\
\text { city }\end{array}$ & & & & & & $x$ & & & \\
\hline 17 & $\begin{array}{l}\% \text { staff use email in their } \\
\text { work }\end{array}$ & & & $x$ & $x$ & $x$ & $x$ & & & \\
\hline 18 & $\begin{array}{l}\% \text { management and } \\
\text { direction information from } \\
\text { provincial leaders on the } \\
\text { official internal website of } \\
\text { the people's committee at } \\
\text { provincial level }\end{array}$ & & & & & $x$ & $x$ & & & \\
\hline 19 & $\begin{array}{l}\% \text { online public } \\
\text { administration service }\end{array}$ & & & & & $x$ & $x$ & & & \\
\hline 20 & $\begin{array}{l}\text { Level of online public } \\
\text { administration service }\end{array}$ & & & & $x$ & $x$ & $x$ & & & \\
\hline
\end{tabular}


Table A.6 continued

\begin{tabular}{|c|c|c|c|c|c|c|c|c|c|c|}
\hline No & Subindicators & 2005 & 2006 & 2007 & 2009 & 2010 & 2011 & 2012 & 2013 & 2014 \\
\hline 21 & $\begin{array}{l}\% \text { staff in public agencies } \\
\text { granted email }\end{array}$ & & & & & $x$ & & & & \\
\hline 22 & $\begin{array}{l}\text { Frequency of update } \\
\text { website }\end{array}$ & & & & & $x$ & & & & \\
\hline 23 & $\begin{array}{l}\text { Public services provided in } \\
\text { Internet }\end{array}$ & & $x$ & $x$ & & & & & & \\
\hline 24 & $\begin{array}{l}\text { \% payment for IT } \\
\text { application (software, } \\
\text { service, consulting, other) } \\
\text { per person in } 3 \text { years } 2005 \text {, } \\
2006,2007\end{array}$ & & & $x$ & & & & & & \\
\hline 25 & $\begin{array}{l}\text { \% payment for IT } \\
\text { application (software, } \\
\text { service, consulting, other) } \\
\text { per person in } 2007\end{array}$ & & & $x$ & & & & & & \\
\hline 26 & $\begin{array}{l}\% \text { payment from budget for } \\
\text { IT application (software, } \\
\text { service, consulting, other) } \\
\text { per person in } 3 \text { years } 2005 \text {, } \\
2006,2007\end{array}$ & & & $x$ & & & & & & \\
\hline 27 & $\begin{array}{l}\% \text { public administration } \\
\text { service in Internet }\end{array}$ & & & $\mathrm{x}$ & & & & & & \\
\hline 28 & $\begin{array}{l}\text { \% payment from budget for } \\
\text { IT application }\end{array}$ & & & & $x$ & & & & & \\
\hline 29 & $\begin{array}{l}\% \text { operating and directing } \\
\text { information upload to } \\
\text { Internet }\end{array}$ & & & & $x$ & & & & & \\
\hline 30 & $\begin{array}{l}\text { Level of deploy document } \\
\text { management software and } \\
\text { operating jobs }\end{array}$ & & & & $x$ & & & & & \\
\hline 31 & $\begin{array}{l}\text { Level of deploy website of } \\
\text { province level }\end{array}$ & & & & $x$ & & & & & \\
\hline \multicolumn{2}{|c|}{ Number of criteria by year } & 7 & 7 & 11 & 7 & 10 & 10 & 9 & 9 & 9 \\
\hline
\end{tabular}

$I C T=$ information and communication technology, IT = information technology.

Source: Authors' computation based on the Government of Viet Nam's official publications. 


\section{2 | Appendix}

Table A.6 continued

(d) Manufacturing and Business Index

\begin{tabular}{|c|c|c|c|c|c|c|c|c|c|c|}
\hline No & Subindicators & 2005 & 2006 & 2007 & 2009 & 2010 & 2011 & 2012 & 2013 & 2014 \\
\hline 1 & $\begin{array}{l}\text { Number of sales and } \\
\text { production units in ICT per } \\
1,000 \text { inhabitants }\end{array}$ & $x$ & $x$ & & & & & & & \\
\hline 2 & $\begin{array}{l}\text { Total revenue of sales and } \\
\text { production units in ICT per } \\
\text { capita }\end{array}$ & $x$ & $x$ & & & & & & & \\
\hline 3 & $\begin{array}{l}\% \text { ICT production, } \\
\text { business units per } 1,000 \\
\text { inhabitants }\end{array}$ & & & $x$ & & & $x$ & $x$ & $x$ & $x$ \\
\hline 4 & $\begin{array}{l}\% \text { person who worked in } \\
\text { ICT production, business } \\
\text { units per } 1,000 \text { inhabitants }\end{array}$ & & & $x$ & & & $x$ & $x$ & $x$ & $x$ \\
\hline 5 & $\begin{array}{l}\% \text { ICT enterprise per } 1,000 \\
\text { inhabitants }\end{array}$ & & & & $x$ & $x$ & & & & \\
\hline 6 & $\begin{array}{l}\text { \% employee in ICT } \\
\text { enterprise per inhabitants }\end{array}$ & & & & $x$ & & & & & \\
\hline 7 & $\begin{array}{l}\% \text { turnover production - } \\
\text { business of ICT enterprise } \\
\text { per inhabitants }\end{array}$ & & & & $x$ & $x$ & $x$ & & & \\
\hline 8 & $\begin{array}{l}\text { \% employee in ICT } \\
\text { enterprise per 10,000 } \\
\text { inhabitants }\end{array}$ & & & & & $x$ & & & & \\
\hline 9 & $\begin{array}{l}\% \text { turnover per staff in ICT } \\
\text { enterprise }\end{array}$ & & & & & & & $x$ & $x$ & $x$ \\
\hline \multicolumn{2}{|c|}{ Number of criteria } & 2 & 2 & 2 & 3 & 3 & 3 & 3 & 3 & 3 \\
\hline
\end{tabular}

ICT = information and communication technology.

Source: Authors' computation based on the Government of Viet Nam's official publications. 
(e) Organization and Policy Environment Index

\begin{tabular}{|c|c|c|c|c|c|c|c|c|c|c|}
\hline No & Subindicators & 2005 & 2006 & 2007 & 2009 & 2010 & 2011 & 2012 & 2013 & 2014 \\
\hline 1 & $\begin{array}{l}\text { Are there administrative } \\
\text { agencies for direction and } \\
\text { management on ICT } \\
\text { (Direction Department on } \\
\text { ICT, Posts and } \\
\text { Telecommunication } \\
\text { Department at provincial } \\
\text { level): Is there Direction } \\
\text { Department at provincial } \\
\text { level on ICT? Number of } \\
\text { meetings per year of the } \\
\text { department? Is there Posts } \\
\text { and Telecommunication } \\
\text { Department at provincial } \\
\text { level? }\end{array}$ & $x$ & $x$ & $x$ & & & & & & \\
\hline 2 & $\begin{array}{l}\text { Are there any policies in } \\
\text { promoting the use and } \\
\text { development of ICT: } \\
\text { Strategies to develop and } \\
\text { apply ICT? Strategies to } \\
\text { encourage the use and } \\
\text { development of ICT; } \\
\text { Strategies to develop } \\
\text { human capital for ICT? }\end{array}$ & $x$ & $x$ & $x$ & & & & & & \\
\hline 3 & $\begin{array}{l}\text { The interest of local } \\
\text { government leaders in the } \\
\text { use and development of } \\
\text { ICT is rated at four levels: } \\
\text { Not interested or barely } \\
\text { interested; Interested at } \\
\text { average level; Fairly } \\
\text { interested and Very } \\
\text { interested }\end{array}$ & $x$ & $x$ & $x$ & & & & & & \\
\hline 4 & $\begin{array}{l}\text { Organization - directing } \\
\text { development - IT } \\
\text { applications in the } \\
\text { province/city }\end{array}$ & & & & $x$ & $x$ & $x$ & $x$ & $x$ & $x$ \\
\hline 5 & $\begin{array}{l}\text { Mechanisms - policies for } \\
\text { development - IT } \\
\text { applications in the } \\
\text { province / city }\end{array}$ & & & & $x$ & $x$ & $x$ & $x$ & $x$ & $x$ \\
\hline 6 & $\begin{array}{l}\text { Level of interest of local } \\
\text { government leaders in use } \\
\text { and development of ICT }\end{array}$ & & & & $x$ & $x$ & $x$ & $x$ & $x$ & $x$ \\
\hline \multicolumn{2}{|c|}{ Number of criteria } & 3 & 3 & 3 & 3 & 3 & 3 & 3 & 3 & 3 \\
\hline
\end{tabular}

$I C T=$ information and communication technology, $I T$ = information technology.

Source: Authors' computation based on official documents from Viet Nam's Ministry of Science and Technology. 
34 | Appendix

Table A.7: Female Comparative Advantage and Task Complexity by Industry

\begin{tabular}{|c|c|c|c|}
\hline ISIC (rev 4) & Description & Task Complexity & $\begin{array}{l}\text { Nonroutine, } \\
\text { Manual, and } \\
\text { Physical Tasks }\end{array}$ \\
\hline 620 & Computer programming & 0.681 & -0.605 \\
\hline 711 & $\begin{array}{l}\text { Architectural and engineering activities and related } \\
\text { technical consultancy }\end{array}$ & 0.646 & -0.685 \\
\hline 262 & $\begin{array}{l}\text { Manufacture of computers and peripheral } \\
\text { equipment }\end{array}$ & 0.638 & -0.178 \\
\hline 721 & $\begin{array}{l}\text { Research and experimental development on natural } \\
\text { sciences and engineering }\end{array}$ & 0.630 & -0.696 \\
\hline 722 & $\begin{array}{l}\text { Research and experimental development on social } \\
\text { sciences and humanities }\end{array}$ & 0.630 & -0.696 \\
\hline 582 & Software publishing & 0.588 & -0.415 \\
\hline 263 & Manufacture of communication equipment & 0.582 & -0.138 \\
\hline 266 & Manufacture of irradiation & 0.582 & -0.152 \\
\hline 265 & Manufacture of measuring & 0.575 & -0.135 \\
\hline 712 & Technical testing and analysis & 0.571 & -0.499 \\
\hline 303 & $\begin{array}{l}\text { Manufacture of air and spacecraft and related } \\
\text { machinery }\end{array}$ & 0.567 & -0.166 \\
\hline 261 & Manufacture of electronic components and boards & 0.566 & -0.073 \\
\hline 267 & $\begin{array}{l}\text { Manufacture of optical instruments and } \\
\text { photographic equipment }\end{array}$ & 0.563 & -0.185 \\
\hline 611 & Wired telecommunications activities & 0.556 & -0.854 \\
\hline 631 & Data processing & 0.550 & -0.506 \\
\hline 61 & Extraction of crude petroleum & 0.547 & -0.116 \\
\hline 62 & Extraction of natural gas & 0.547 & -0.116 \\
\hline 701 & Activities of head offices & 0.541 & -0.675 \\
\hline 801 & Private security activities & 0.540 & -0.440 \\
\hline 802 & Security systems service activities & 0.540 & -0.438 \\
\hline 702 & Management consultancy activities & 0.536 & -0.675 \\
\hline 613 & Satellite telecommunications activities & 0.534 & -0.854 \\
\hline 691 & Legal activities & 0.533 & -0.675 \\
\hline 210 & Manufacture of pharmaceuticals & 0.533 & -0.060 \\
\hline 749 & Other professional & 0.531 & -0.528 \\
\hline 71 & Mining of iron ores & 0.530 & 0.069 \\
\hline 72 & Mining of nonferrous metal ores & 0.530 & 0.069 \\
\hline 619 & Other telecommunications activities & 0.524 & -0.854 \\
\hline 332 & Installation of industrial machinery and equipment & 0.521 & -0.256 \\
\hline 51 & Mining of hard coal & 0.521 & 0.001 \\
\hline
\end{tabular}




\begin{tabular}{|c|c|c|c|}
\hline ISIC (rev 4) & Description & Task Complexity & $\begin{array}{l}\text { Nonroutine, } \\
\text { Manual, and } \\
\text { Physical Tasks }\end{array}$ \\
\hline 692 & Accounting & 0.520 & -0.675 \\
\hline 803 & Investigation activities & 0.517 & -0.440 \\
\hline 191 & Manufacture of coke oven products & 0.515 & -0.181 \\
\hline 432 & Electrical & 0.515 & -0.522 \\
\hline 192 & Manufacture of refined petroleum products & 0.514 & -0.116 \\
\hline 429 & Construction of other civil engineering projects & 0.514 & -0.584 \\
\hline 493 & Transport via pipeline & 0.514 & -0.469 \\
\hline 203 & Manufacture of man-made fibers & 0.513 & -0.107 \\
\hline 422 & Construction of utility projects & 0.513 & -0.522 \\
\hline 410 & Construction of buildings & 0.512 & -0.522 \\
\hline 302 & Manufacture of railway locomotives and rolling stock & 0.512 & -0.128 \\
\hline 602 & Television programming and broadcasting activities & 0.509 & -0.173 \\
\hline 182 & Reproduction of recorded media & 0.509 & -0.031 \\
\hline 268 & Manufacture of magnetic and optical media & 0.509 & -0.106 \\
\hline 811 & Combined facilities support activities & 0.509 & -0.616 \\
\hline 774 & Leasing of intellectual property and similar products & 0.507 & -0.639 \\
\hline 433 & Building completion and finishing & 0.506 & -0.520 \\
\hline 741 & Specialized design activities & 0.504 & -0.563 \\
\hline 271 & Manufacture of electric motors & 0.503 & -0.021 \\
\hline 279 & Manufacture of other electrical equipment & 0.503 & -0.082 \\
\hline 601 & Radio broadcasting & 0.503 & -0.173 \\
\hline 201 & Manufacture of basic chemicals & 0.503 & -0.084 \\
\hline 264 & Manufacture of consumer electronics & 0.502 & -0.140 \\
\hline 331 & Repair of fabricated metal products & 0.502 & -0.176 \\
\hline 99 & Support activities for other mining and quarrying & 0.501 & -0.064 \\
\hline 282 & Manufacture of special-purpose machinery & 0.501 & -0.227 \\
\hline 439 & Other specialized construction activities & 0.498 & -0.521 \\
\hline 452 & Maintenance and repair of motor vehicles & 0.497 & -0.540 \\
\hline 431 & Demolition and site preparation & 0.497 & -0.522 \\
\hline 421 & Construction of roads and railways & 0.497 & -0.522 \\
\hline 592 & Sound recording and music publishing activities & 0.496 & -0.104 \\
\hline 612 & Wireless telecommunications activities & 0.496 & -0.854 \\
\hline 732 & Market research and public opinion polling & 0.495 & -0.675 \\
\hline 281 & Manufacture of general-purpose machinery & 0.495 & -0.181 \\
\hline 52 & Mining of lignite & 0.495 & -0.093 \\
\hline 120 & Manufacture of tobacco products & 0.492 & -0.062 \\
\hline
\end{tabular}


36 | Appendix

Table A.7 continued

\begin{tabular}{|c|c|c|c|}
\hline ISIC (rev 4) & Description & Task Complexity & $\begin{array}{l}\text { Nonroutine, } \\
\text { Manual, and } \\
\text { Physical Tasks }\end{array}$ \\
\hline 325 & $\begin{array}{l}\text { Manufacture of medical and dental instruments } \\
\text { and supplies }\end{array}$ & 0.491 & -0.148 \\
\hline 293 & $\begin{array}{l}\text { Manufacture of parts and accessories for motor } \\
\text { vehicles }\end{array}$ & 0.491 & -0.067 \\
\hline 291 & Manufacture of motor vehicles & 0.491 & -0.115 \\
\hline 681 & Real estate activities with own or leased property & 0.491 & -0.606 \\
\hline 301 & Building of ships and boats & 0.490 & -0.160 \\
\hline 309 & Manufacture of transport equipment n.e.c. & 0.488 & -0.190 \\
\hline 273 & Manufacture of wiring and wiring devices & 0.487 & -0.057 \\
\hline 202 & Manufacture of other chemical products & 0.487 & -0.102 \\
\hline 252 & Manufacture of weapons and ammunition & 0.486 & -0.301 \\
\hline 272 & Manufacture of batteries and accumulators & 0.483 & 0.085 \\
\hline 742 & Photographic activities & 0.482 & -0.140 \\
\hline 274 & Manufacture of electric lighting equipment & 0.481 & 0.018 \\
\hline 241 & Manufacture of basic iron and steel & 0.480 & -0.259 \\
\hline 682 & Real estate activities on a fee or contract basis & 0.480 & -0.591 \\
\hline 275 & Manufacture of domestic appliances & 0.480 & 0.030 \\
\hline 243 & Casting of metals & 0.480 & -0.271 \\
\hline 581 & Publishing of books & 0.478 & -0.192 \\
\hline 242 & $\begin{array}{l}\text { Manufacture of basic precious and other nonferrous } \\
\text { metals }\end{array}$ & 0.478 & -0.133 \\
\hline 329 & Other manufacturing n.e.c. & 0.478 & -0.044 \\
\hline 292 & $\begin{array}{l}\text { Manufacture of bodies (coachwork) for motor } \\
\text { vehicles; manufacture of trailers and semi-trailers }\end{array}$ & 0.476 & -0.239 \\
\hline 251 & Manufacture of structural metal products & 0.476 & -0.240 \\
\hline 259 & $\begin{array}{l}\text { Manufacture of other fabricated metal products; } \\
\text { metalworking service activities }\end{array}$ & 0.475 & -0.184 \\
\hline 591 & Motion picture & 0.473 & -0.052 \\
\hline 221 & Manufacture of rubber products & 0.470 & 0.003 \\
\hline 323 & Manufacture of sports goods & 0.470 & 0.048 \\
\hline 322 & Manufacture of musical instruments & 0.470 & -0.089 \\
\hline 324 & Manufacture of games and toys & 0.470 & -0.089 \\
\hline 321 & Manufacture of jewelry & 0.468 & -0.117 \\
\hline 222 & Manufacture of plastics products & 0.468 & -0.015 \\
\hline 152 & Manufacture of footwear & 0.467 & 0.186 \\
\hline 170 & Manufacture of paper and paper products & 0.466 & -0.044 \\
\hline 143 & Manufacture of knitted and crocheted apparel & 0.466 & 0.047 \\
\hline
\end{tabular}




\begin{tabular}{|c|c|c|c|}
\hline ISIC (rev 4) & Description & Task Complexity & $\begin{array}{l}\text { Nonroutine, } \\
\text { Manual, and } \\
\text { Physical Tasks }\end{array}$ \\
\hline 310 & Manufacture of furniture & 0.464 & -0.133 \\
\hline 131 & Spinning & 0.463 & 0.015 \\
\hline 239 & Manufacture of nonmetallic mineral products n.e.c. & 0.462 & -0.009 \\
\hline 231 & Manufacture of glass and glass products & 0.462 & 0.041 \\
\hline 142 & Manufacture of articles of fur & 0.461 & 0.092 \\
\hline 731 & Advertising & 0.461 & -0.568 \\
\hline 162 & Manufacture of products of wood & 0.460 & -0.022 \\
\hline 151 & $\begin{array}{l}\text { Tanning and dressing of leather; manufacture of } \\
\text { luggage }\end{array}$ & 0.459 & 0.109 \\
\hline 91 & $\begin{array}{l}\text { Support activities for petroleum and natural gas } \\
\text { extraction }\end{array}$ & 0.458 & -0.418 \\
\hline 141 & Manufacture of wearing apparel & 0.457 & 0.055 \\
\hline 81 & Quarrying of stone & 0.455 & 0.065 \\
\hline 106 & Manufacture of grain mill products & 0.455 & -0.013 \\
\hline 104 & Manufacture of vegetable and animal oils and fats & 0.454 & -0.013 \\
\hline 89 & Mining and quarrying n.e.c. & 0.454 & 0.063 \\
\hline 181 & Printing and service activities related to printing & 0.453 & 0.005 \\
\hline 465 & Wholesale of machinery & 0.452 & -0.268 \\
\hline 823 & Organization of conventions and trade shows & 0.452 & -0.440 \\
\hline 750 & Veterinary activities & 0.452 & -0.460 \\
\hline 101 & Processing and preserving of meat & 0.449 & -0.013 \\
\hline 103 & Processing and preserving of fruit and vegetables & 0.447 & -0.016 \\
\hline 781 & Activities of employment placement agencies & 0.443 & -0.070 \\
\hline 782 & Temporary employment agency activities & 0.443 & -0.440 \\
\hline 783 & Other human resources provision & 0.443 & -0.440 \\
\hline 107 & Manufacture of other food products & 0.442 & -0.026 \\
\hline 105 & Manufacture of dairy products & 0.442 & -0.013 \\
\hline 31 & Fishing & 0.440 & -0.380 \\
\hline 102 & Processing and preserving of fish & 0.440 & -0.013 \\
\hline 108 & Manufacture of prepared animal feeds & 0.439 & -0.013 \\
\hline 821 & Office administrative and support activities & 0.434 & -0.185 \\
\hline 161 & Sawmilling and planing of wood & 0.433 & -0.115 \\
\hline 110 & Manufacture of beverages & 0.432 & -0.093 \\
\hline 512 & Freight air transport & 0.430 & -0.269 \\
\hline 812 & Cleaning activities & 0.427 & -0.237 \\
\hline 454 & Sale & 0.427 & -0.296 \\
\hline
\end{tabular}


38 | Appendix

Table A.7 continued

\begin{tabular}{|c|c|c|c|}
\hline ISIC (rev 4) & Description & Task Complexity & $\begin{array}{c}\text { Nonroutine, } \\
\text { Manual, and } \\
\text { Physical Tasks }\end{array}$ \\
\hline 511 & Passenger air transport & 0.427 & -0.269 \\
\hline 829 & Business support service activities n.e.c. & 0.427 & -0.440 \\
\hline 773 & Renting and leasing of other machinery & 0.422 & -0.454 \\
\hline 451 & Sale of motor vehicles & 0.422 & -0.250 \\
\hline 474 & $\begin{array}{l}\text { Retail sale of information and communications } \\
\text { equipment in specialized stores }\end{array}$ & 0.421 & -0.322 \\
\hline 464 & Wholesale of household goods & 0.419 & -0.241 \\
\hline 491 & Transport via railways & 0.417 & -0.200 \\
\hline 479 & Retail trade not in stores & 0.416 & -0.028 \\
\hline 453 & Sale of motor vehicle parts and accessories & 0.414 & -0.254 \\
\hline 822 & Activities of call centers & 0.407 & -0.440 \\
\hline 531 & Postal activities & 0.406 & 0.325 \\
\hline 461 & Wholesale on a fee or contract basis & 0.405 & -0.163 \\
\hline 466 & Other specialized wholesale & 0.402 & -0.247 \\
\hline 551 & Short term accommodation activities & 0.399 & 0.052 \\
\hline 522 & Support activities for transportation & 0.398 & -0.392 \\
\hline 813 & Landscape care and maintenance service activities & 0.397 & -0.041 \\
\hline 469 & Nonspecialized wholesale trade & 0.396 & -0.237 \\
\hline 559 & Other accommodation & 0.396 & 0.052 \\
\hline 791 & Travel agency and tour operator activities & 0.394 & -0.401 \\
\hline 478 & Retail sale via stalls and markets & 0.391 & -0.028 \\
\hline 771 & Renting and leasing of motor vehicles & 0.388 & -0.454 \\
\hline 462 & $\begin{array}{l}\text { Wholesale of agricultural raw materials and live } \\
\text { animals }\end{array}$ & 0.385 & -0.207 \\
\hline 463 & Wholesale of food & 0.381 & -0.207 \\
\hline 477 & Retail sale of other goods in specialized stores & 0.379 & -0.324 \\
\hline 521 & Warehousing and storage & 0.375 & -0.401 \\
\hline 22 & Logging & 0.374 & -0.430 \\
\hline 24 & Support services to forestry & 0.374 & -0.430 \\
\hline 501 & Sea and coastal water transport & 0.373 & -0.300 \\
\hline 475 & $\begin{array}{l}\text { Retail sale of other household equipment in } \\
\text { specialized stores }\end{array}$ & 0.372 & -0.322 \\
\hline 16 & $\begin{array}{l}\text { Support activities to agriculture and postharvest } \\
\text { crop activities }\end{array}$ & 0.369 & -0.239 \\
\hline 492 & Other land transport & 0.368 & 0.024 \\
\hline 472 & Retail sale of food & 0.366 & -0.293 \\
\hline 772 & Renting and leasing of personal and household goods & 0.366 & -0.454 \\
\hline
\end{tabular}




\begin{tabular}{llcc}
\hline ISIC (rev 4) & \multicolumn{1}{c}{ Description } & Task Complexity & $\begin{array}{c}\text { Nonroutine, } \\
\text { Manual, and } \\
\text { Physical Tasks }\end{array}$ \\
\hline 476 & $\begin{array}{l}\text { Retail sale of cultural and recreation goods in } \\
\text { specialized stores }\end{array}$ & 0.366 & -0.322 \\
532 & Courier activities & 0.364 & 0.325 \\
471 & Retail sale in nonspecialized stores & 0.363 & -0.275 \\
502 & Inland water transport & 0.361 & -0.300 \\
562 & Event catering and other food service activities & 0.343 & 0.354 \\
473 & Retail sale of automotive fuel in specialized stores & 0.341 & -0.158 \\
563 & Beverage serving activities & 0.335 & 0.354 \\
561 & Restaurants and mobile food service activities & 0.328 & 0.354 \\
12 & Growing of perennial crops & & -0.234 \\
23 & Gathering of nonwood forest products & & -0.290 \\
13 & Plant propagation & & -0.325 \\
15 & Mixed farming & & -0.236 \\
14 & Animal production & & -0.257 \\
32 & Aquaculture & & -0.319 \\
21 & Silviculture and other forestry activities & & -0.430 \\
11 & Growing of nonperennial crops & & -0.220 \\
\hline
\end{tabular}

ISIC = International Standard Industrial Classification, n.e.c. = not elsewhere classified.

Sources: Complexity (Keller and Yeaple 2008). Nonroutine, physical, and manual (Acemoglu and Autor 2011). 


\section{REFERENCES}

Acemoglu, Daron, and David H. Autor. 2011. "Chapter 12: Skills Tasks and Technologies: Implications for Employment and Earnings.” Handbook of Labor Economics, 1043-71. Elsevier.

Akerman, Anders, Ingvil Gaarder, and Magne Mogstad. 2015. "The Skill Complementarity of Broadband Internet." Quarterly Journal of Economics 130 (4): 1781-824.

Autor, David H., David Dorn, and Gordon Howard Hanson. 2016. "The China Shock: Learning from Labor Market Adjustment to Large Changes in Trade." Annual Review of Economics 8: 205-40.

Autor, David H., Lawrence Francis Katz, and Alan Bennett Krueger. 1998. "Computing Inequality: Have Computers Changed the Labor Market?” Quarterly Journal of Economics 113 (4): 1169-213.

Autor, David H., Frank Levy, and Richard J. Murnane. 2003. "The Skill Content of Recent Technological Change: An Empirical Exploration." Quarterly Journal of Economics 118 (4): 1279-333.

Bartel, Ann P., Casey Ichniowski, and Kathryn L. Shaw. 2007. "How Does Information Technology Affect Productivity? Plant-Level Comparisons of Product Innovation, Process Improvement, and Worker Skills." Quarterly Journal of Economics 122 (4): 1721-58.

Black, Sandra Eilene, and Lisa M. Lynch. 2001. "How to Compete: The Impact of Work-Place Practices and Information Technology on Productivity." Review of Economics and Statistics 83 (3): 434-45.

Black, Sandra Eilene, and Alexandra Spitz-Oener. 2010. “Explaining Women’s Success: Technological Change and Skill Content of Women's Work." Review of Economics and Statistics 92 (1): 187-94.

Bloom, Nicholas, Luis Garciano, Raffaella Sadun, John Van Van Reenan. 2014. "The Distinct Effects of Information Technology and Communication Technology on Firm Organization." Management Science 60 (2): 2859-85.

Bresnahan, Timothy F., Erik Brynjolfsson, Lorin M. Hitt. 2002. "Information Technology, Workplace Organization and the Demand for Skilled Labor: Firm Level Evidence." Quarterly Journal of Economics 117 (1): 339-76.

Brynjolfsson, Erik, and Lorin M. Hitt. 2003. "Computing Productivity: Firm-level Evidence." Review of Economics and Statistics 85 (4): 793-808.

Commander, Simon, Rupert Harrison, and Naercio Menezes-Filho. 2011. "ICT and Productivity in Developing Countries: New Firm-Level Evidence from Brazil and India." Review of Economics and Statistics 93 (2): 528-41.

Crandall, Robert, William Lehr, and Robert Litan. 2007. "The Effects of Broadband Deployment on Output and Employment. A Cross-sectional Analysis of U.S. Data." Issues in Economic Policy No. 6. The Brookings Institution. 
Dinkelman, Taryn. 2011. "The Effects of Rural Electrification on Employment: New Evidence from South Africa." American Economic Review 101 (7): 3078-108.

Duflo, Esther, and Rohini Pande. 2007. “Dams.” Quarterly Journal of Economics 122 (2): 601-46.

Forman, Chris, Avi Goldfarb, and Shane Greenstein. 2012. "The Internet and Local Wages: A Puzzle." American Economic Review 102 (1): 556-75.

Goldin, Claudia. 2006. “The Quiet Revolution That Transformed Women's Employment, Education, and Family." Ely Lecture, American Economic Review, Papers and Proceedings 96 (2): 1-21.

Grimes, Arthur, Cleo Ren, and Philip Stevens. 2012. "The Need for Speed: Impacts of Internet Connectivity on Firm Productivity.” Journal of Productivity Analysis 37 (2): 187-201.

Guiso, Luigi, Ferdinando Monte, Paola Sapienza, and Luigi Zingales. 2008. "Culture, Gender, and Math." Science 320 (5880): 1164-65.

Hjort, Jonas, and Jonas Poulsen. 2017. "The Arrival of Fast Internet and Employment in Africa." NBER Working Paper No. 23582.

Jensen, Robert. 2007. "The Digital Provide: Information (Technology), Market Performance, and Welfare in the South Indian Fisheries Sector." Quarterly Journal of Economics 122 (3): 879-924.

Juhn, Chinhui, Gergely Ujhelyi, and Carolina Villegas-Sanchez. 2014. "Men, Women, and Machines: How Trade Impacts Gender Inequality.” Journal of Development Economics 106: 179-93.

Keller, Wolfgang, and Stephen Yeaple. 2008. "Global Production and Trade in the Knowledge Economy.” NBER Working Paper No. 14626.

Lindley, Joanne. 2012. "The Gender Dimension of Technical Change and the Role of Task Inputs. Labour Economics 19 (4): 512-26.

Mathiowetz, Virgil, Nancy Kashman, Gloria Volland, Karen Weber, Mary Dowe, and Sandra Rogers. 1985. "Grip and Pinch Strength: Normative Data for Adults." Archives of Physical Medicine and Rehabilitation 66 (2): 69-74.

Michaels, Guy, Ashwini Natraj, and John Van Reenen. 2014. "Has ICT Polarized Skill Demand? Evidence from Eleven Countries Over Twenty-Five Years." Review of Economics and Statistics 96 (1): 60-77.

Newman, Carol, and Finn Tarp. 2014, Technology and Competitiveness in Viet Nam. Presentation link: https://www3.wider.unu.edu/sites/default/files/Technology-competitiveness-in-VietNam5772.pdf.

Ngai, L. Rachel, and Barbara Petrongolo. 2017. "Gender Gaps and the Rise of the Service Economy." American Economic Journal: Macroeconomics 9 (4): 1-44. 
Nguyen, Viet Ha. 2013. "Despite Rapid Modernization in Viet Nam, Survey Reveals Gender Bias Persists Among Youth." The Asia Foundation. March 6. https://asiafoundation.org/2013/03/06/ despite-rapid-modernization-in-vietnam-survey-reveals-gender-bias-persists-among-youth/.

Ogutu, Sylvester Ochieng, Julius Juma Okello, and David Jakinda Otieno. 2014. "Impact of Information and Communication Technology-Based Market Information Services on Smallholder Farm Input Use and Productivity: The Case of Kenya." World Development 64: 311-21.

Olivetti, Claudia, and Barbara Petrongolo. 2016, "The Evolution of Gender Gaps in Industrialized Countries." Annual Review of Economics 8 (1): 405-34.

Piketty, Thomas. 2014. Capital in the Twenty First Century Belknap Press: An Imprint of Harvard University Press.

Pitt, Mark M., Mark R. Rosenzweig, and Md. Nazmul Hassan. 2012. "Human Capital Investment and the Gender Division of Labor in a Brawn-Based Economy." American Economic Review 102 (7): 3531-60.

Stock, James H., and Motohiro Yogo. 2005. "Testing for Weak Instruments in Linear IV Regression" Book." Identification and Inference for Econometric Models: Essays in Honor of Thomas Rothenberg, 80-108. Cambridge University Press

Tambe, Prasanna, Lorin M. Hitt, and Erik Brynjolfsson. 2012. "The Extroverted Firm: How External Information Practices Affect Innovation and Productivity." Management Science 58 (5): 843-59.

Tuan, Tran Minh. 2011. Broadband in Viet Nam: Forging Its Own Path. Washington, DC: infoDev/World Bank.

UNESCO and KWDI. 2015. A Complex Formula: Girls and Women in Science, Technology, Engineering and Mathematics in Asia. Paris: UNESCO.

United Nations Statistics Division. https://unstats.un.org/unsd/cr/registry/regot.asp? Lg=1.

World Bank. 2017. World Development Indicators. http://databank.worldbank.org/data/reports.aspx? source=world-development-indicators (accessed 10 October 2017).

World Trade Organization (WTO). 2017. Tariff Download Facility. http://tariffdata.wto.org/ ReportersAndProducts.aspx (accessed August 2017). 


\section{Do Information and Communication Technologies Empower Female Workers? Firm-level Evidence from Viet Nam}

Using Viet Nam's comprehensive enterprise survey data, this paper finds that a firm's adoption of broadband Internet and related information and communication technologies (ICT) increased their relative demand for female and college-educated workers. The effect of ICT on a firm's female employment is particularly strong among the college-educated employees and is weaker in industries that are more dependent on complex and interactive tasks. These results suggest that ICT reduces inequalities in female employment by creating a shift in labor demand from highly manual, routine tasks, where males have a comparative advantage toward more nonroutine tasks, where females hold a comparative advantage.

\section{About the Asian Development Bank}

ADB's vision is an Asia and Pacific region free of poverty. Its mission is to help its developing member countries reduce poverty and improve the quality of life of their people. Despite the region's many successes, it remains home to a large share of the world's poor. ADB is committed to reducing poverty through inclusive economic growth, environmentally sustainable growth, and regional integration.

Based in Manila, ADB is owned by 67 members, including 48 from the region. Its main instruments for helping its developing member countries are policy dialogue, loans, equity investments, guarantees, grants, and technical assistance.

$\mathrm{ADB}$ 